Prepared in cooperation with the Upper Colorado River Wild and Scenic Stakeholder Group and the Colorado River Water Conservation District

\title{
Incipient Bed-Movement and Flood-Frequency Analysis using Hydrophones to Estimate Flushing Flows on the Upper Colorado River, Colorado, 2019
}

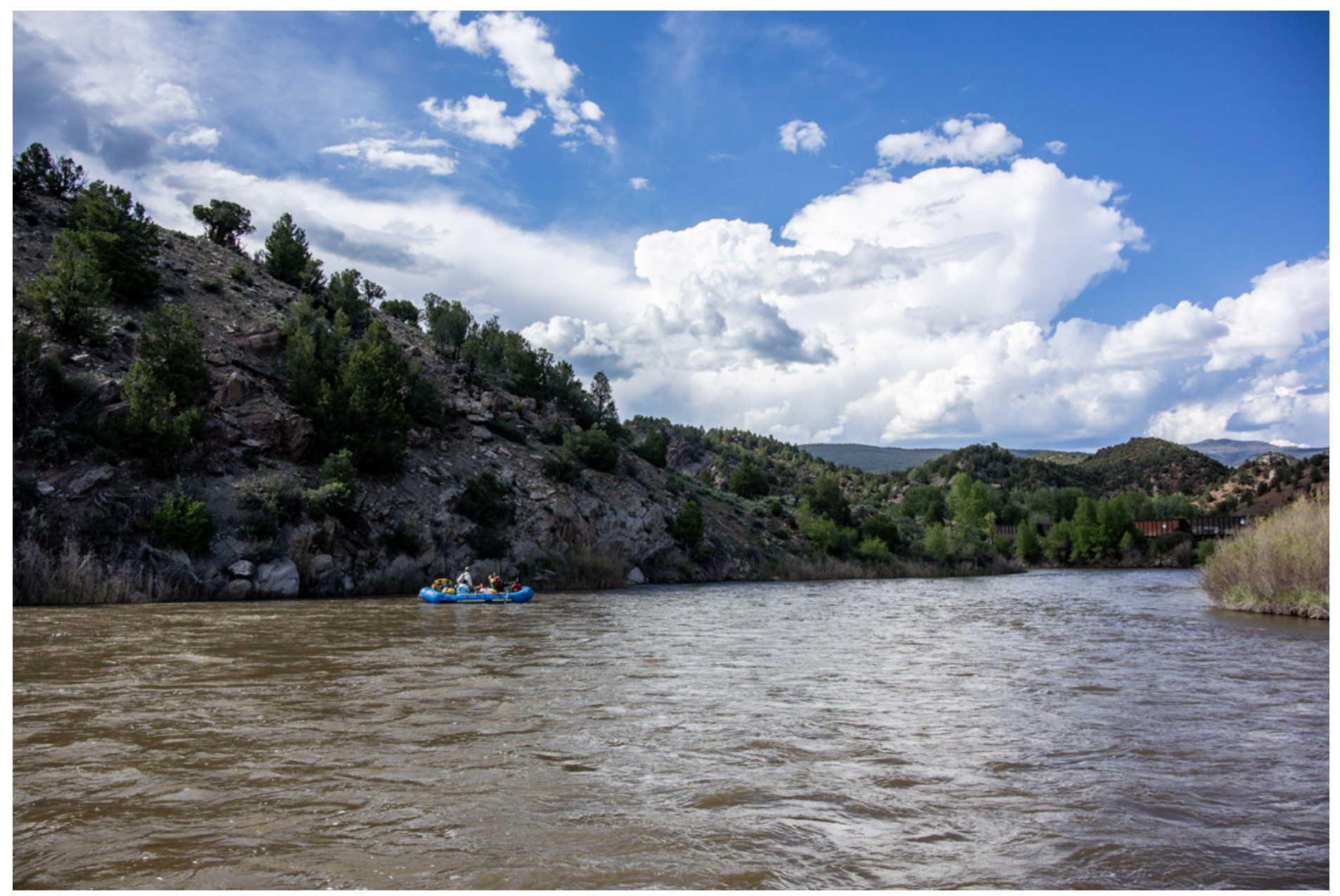

Scientific Investigations Report 2020-5069 
Cover photograph. Colorado River near McCoy, Colorado, looking north (downstream) on June 6, 2020, during underwater acoustic data collection. (Photo taken by Rich McDonald, USGS). 


\section{Incipient Bed-Movement and \\ Flood-Frequency Analysis using \\ Hydrophones to Estimate Flushing Flows on the Upper Colorado River, Colorado, 2019}

By Michael S. Kohn, Mathieu D. Marineau, Laura A. Hempel, and

Richard R. McDonald

Prepared in cooperation with the Upper Colorado River Wild and Scenic

Stakeholder Group and the Colorado River Water Conservation District

Scientific Investigations Report 2020-5069 


\title{
U.S. Department of the Interior \\ DAVID BERNHARDT, Secretary
}

\author{
U.S. Geological Survey \\ James F. Reilly II, Director
}

U.S. Geological Survey, Reston, Virginia: 2020

For more information on the USGS - the Federal source for science about the Earth, its natural and living resources, natural hazards, and the environment-visit https://www.usgs.gov or call 1-888-ASK-USGS.

For an overview of USGS information products, including maps, imagery, and publications, visit https://store.usgs.gov/.

Any use of trade, firm, or product names is for descriptive purposes only and does not imply endorsement by the U.S. Government.

Although this information product, for the most part, is in the public domain, it also may contain copyrighted materials as noted in the text. Permission to reproduce copyrighted items must be secured from the copyright owner.

Suggested citation:

Kohn, M.S., Marineau, M.D., Hempel, L.A., and McDonald, R.R., 2020, Incipient bed-movement and flood-frequency analysis using hydrophones to estimate flushing flows on the upper Colorado River, Colorado, 2019: U.S. Geological Survey Scientific Investigations Report 2020-5069, 39 p., https://doi.org/10.3133/sir20205069.

Associated data for this publication:

Kohn, M.S., and Hempel, L.A., 2020, Acoustic, spatial, and sediment size data collected on the upper Colorado River to estimate the flushing flows, Colorado, 2019: U.S. Geological Survey Data Release, https://doi.org/10.5066/P9J5L780.

ISSN 2328-0328 (online) 


\section{Acknowledgments}

The authors wish to thank the Upper Colorado River Wild and Scenic Stakeholder Group for funding this study and the Colorado River Water Conservation District for acting as the fiscal agent. The authors are grateful to Rob Buirgy, with the Upper Colorado River Wild and Scenic Stakeholder Group, for his willingness to help with fieldwork and to ensure the data collection was successful, and for sharing his knowledge of the river and the interests of the stakeholders. The authors want to thank Brandy Logan, with the Colorado Water Conservation Board, for her coordination of this project and her ability to find qualified experts to advise and assist us throughout the study. The authors want to express gratitude to the following for their contribution in determining the study sites: David Graf, Kendall Bakich, and Eric Richer, all with Colorado Parks and Wildlife. The authors also want to thank the U.S. Geological Survey National Streamflow Information Program, the Bureau of Land Management, and the Upper Colorado River Wild and Scenic Stakeholder Group for providing funding for the operation and maintenance of the streamgages used for this study. The authors are also grateful to the following individuals for providing access to their properties for data collection: Jake, Judy, and James Stull; Brian Wesbury; Gordon Lewis; and Jack Bombardier; without their collaboration and generosity, this study would not have been possible. 



\section{Contents}

Acknowledgments ……...................................................................................................................

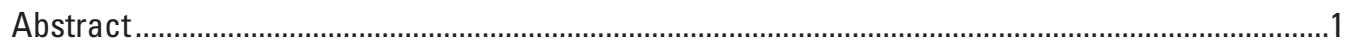

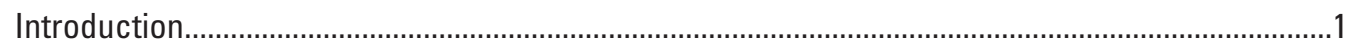

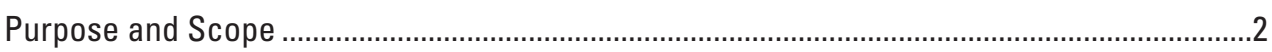

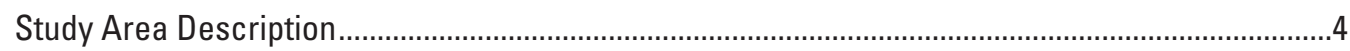

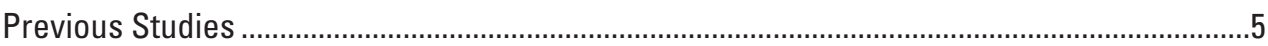

Methods

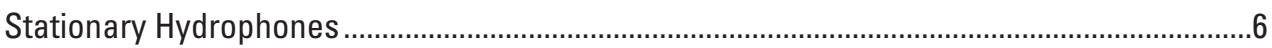

Stationary Underwater Acoustic Data Collection .............................................................6

Stationary Underwater Acoustic Data Processing ...........................................................

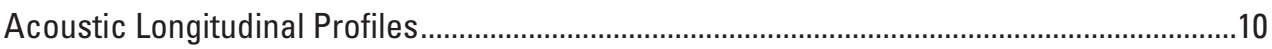

Longitudinal Underwater Acoustic Data Collection ...................................................12

Longitudinal Acoustic Doppler Current Profiler Data Collection .......................................13

Longitudinal Underwater Acoustic Data Processing ....................................................13

Longitudinal Acoustic Doppler Current Profiler Processing ..........................................13

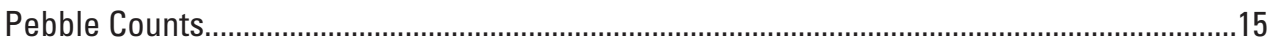

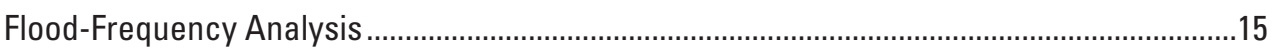

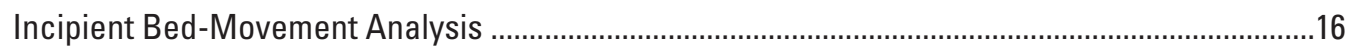

Detection of Gravel-Bed Movement Based on Stationary Hydrophones ..............................16

Longitudinal Profiles.......................................................................................................

Longitudinal Hydrophones ..................................................................................16

Longitudinal Acoustic Doppler Current Profiler ………..............................................25

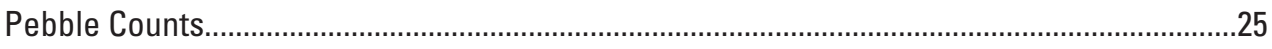

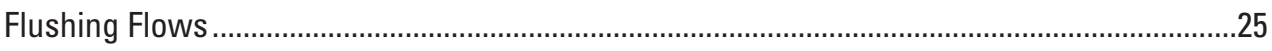

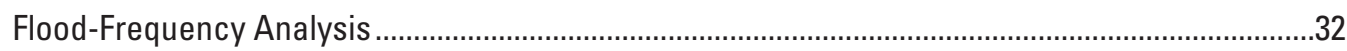

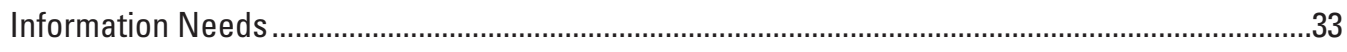

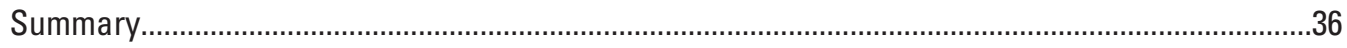

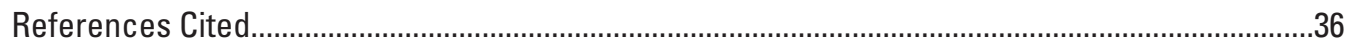

\section{Figures}

1. Map showing the locations of U.S. Geological Survey streamgages and stationary hydrophone sites on the upper Colorado River, Colorado...

2. Graph showing streamflow recorded at 15-minute intervals at the Colorado River near Dotsero, Colorado, streamgage (U.S. Geological Survey [USGS] streamgage number 09070500); Colorado River at Catamount Bridge, Colo., streamgage (USGS streamgage number 09060799); and Colorado River near Kremmling, Colo., streamgage (USGS streamgage number 09058000) from April to August 2019

3. Map showing the stationary hydrophone monitoring reach locations at the Radium stationary hydrophone site

4. Map showing the stationary hydrophone monitoring reach locations at the above Catamount Bridge stationary hydrophone site

5. Photographs of the stationary hydrophone system ............................................................ 
6. Graphs showing streamflow recorded at 15-minute intervals during the June 6-8, 2019, longitudinal profile measured at the Colorado River near Kremmling, Colorado, streamgage (U.S. Geological Survey [USGS] streamgage number 09058000); Colorado River at Catamount Bridge, Colo., streamgage (USGS streamgage number 09060799); and Colorado River near Dotsero, Colo., streamgage (USGS streamgage number 09070500).

7. Graphs showing streamflow recorded at 15-minute intervals during the June 18-19, 2019, longitudinal profile measured at the Colorado River near Kremmling, Colorado, streamgage (U.S. Geological Survey [USGS] streamgage number 09058000) and Colorado River at Catamount Bridge, Colo., streamgage (USGS streamgage number 09060799)

8. Photographs of the mobile hydrophone system and acoustic Doppler current profiler deployment used for the longitudinal profiles

9. Map showing where bed movement was detected or was not detected during the June $6-8,2019$, longitudinal profile.

10. Map showing where bed movement was detected or was not detected during the June 18-19, 2019, longitudinal profile.

11. Maps showing where bed movement was detected or was not detected at the Radium stationary hydrophone monitoring reach locations during the June 6-8, 2019, and June 18-19, 2019, longitudinal profiles.

12. Maps showing where bed movement was detected or was not detected at the above Catamount Bridge stationary hydrophone monitoring reach locations during the June 6-8, 2019, and June 18-19, 2019, longitudinal profiles

13. Maps showing where bed movement was detected or was not detected at the riffle near the Pumphouse Recreation Area during the June 6-8, 2019, and June 18-19, 2019, longitudinal profiles.

14. Maps showing where bed movement was detected or was not detected at the riffle near State Bridge during the June 6-8, 2019, and June 18-19, 2019, longitudinal profiles

15. Map showing where bed movement was detected or was not detected at the riffle below Red Dirt Creek during the June 6-8, 2019, longitudinal profile

16. Graph showing grain-size distributions of Wolman pebble counts (1954) presented as cumulative percent finer particle size at the upstream and downstream above Catamount Bridge stationary hydrophone monitoring reach locations.

17. Graph showing grain-size distributions from Wolman pebble counts (1954) presented as cumulative percent finer particle size at the upstream and downstream Radium stationary hydrophone monitoring reach locations.

18. Graphs showing the number of consecutive days based on historical data and future conditions, where the daily average streamflow exceeded 3,000 cubic feet per second at the U.S. Geological Survey (USGS) streamgage Colorado River near Kremmling, Colorado (USGS streamgage number 09058000)

19. Graphs showing the number of consecutive days based on historical data and future conditions, where the daily average streamflow exceeded 2,400 cubic feet per second at the U.S. Geological Survey (USGS) streamgage Colorado River near Kremmling, Colordao (USGS streamgage number 09058000) 


\section{Tables}

1. Information about the U.S. Geological Survey streamgages in the study area .................4

2. Information on the four hydrophone monitoring reach locations at the two stationary hydrophone sites

3. Descriptions of the bed-movement regimes that were assigned at the Radium and above Catamount Bridge stationary hydrophone sites.

4. The average and range of average streamflows at the Colorado River near Kremmling, Colorado, streamgage 09058000 (Kremmling streamgage) and Colorado River at Catamount Bridge, Colo., streamgage 09060799 (Catamount streamgage) for the different bed-movement regime categories that were assigned at the four stationary hydrophone monitoring reach locations.

5. Streamflow observed at the U.S. Geological Survey streamgages in the study area during the acoustic longitudinal profiles.

6. Summary of the percentage of data points where bed movement was detected in reaches of the upper Colorado River during the June 6-8, 2019, and June 18-19, 2019, longitudinal profiles

7. Streamflow measurements made with an acoustic Doppler current profiler during the June $6-8,2019$, longitudinal profile to summarize the streamflow accumulation in the upper Colorado River Basin

8. Grain sizes of the 16th (D16), 50th (D50, median), and 84th (D84) percentiles from Wolman pebble counts (1954) at the four stationary hydrophone monitoring reach locations

9. Summary of the flood-frequency analyses for seven periods of record for the Colorado River near Kremmling, Colorado streamgage (U.S. Geological Survey streamgage 09058000).

\section{Conversion Factors}

U.S. customary units to International System of Units

\begin{tabular}{lcl}
\hline \multicolumn{1}{c}{ Multiply } & By & \multicolumn{1}{c}{ To obtain } \\
\hline \multicolumn{3}{c}{ Length } \\
foot $(\mathrm{ft})$ & 0.3048 & meter $(\mathrm{m})$ \\
mile $(\mathrm{mi})$ & 1.609 & \multicolumn{1}{c}{ kilometer $(\mathrm{km})$} \\
\hline \multicolumn{2}{c}{ Area } & \\
\hline square foot $\left(\mathrm{ft}^{2}\right)$ & 929.0 & square centimeter $\left(\mathrm{cm}^{2}\right)$ \\
square foot $\left(\mathrm{ft}^{2}\right)$ & 0.09290 & square meter $\left(\mathrm{m}^{2}\right)$ \\
square mile $\left(\mathrm{mi}^{2}\right)$ & 259.0 & hectare $(\mathrm{ha})$ \\
square mile $\left(\mathrm{mi}^{2}\right)$ & 2.590 & square kilometer $\left(\mathrm{km}{ }^{2}\right)$ \\
\hline & Flow rate & \\
\hline foot per second $(\mathrm{ft} / \mathrm{s})$ & 0.3048 & meter per second $(\mathrm{m} / \mathrm{s})$ \\
cubic foot per second $(\mathrm{ft} 3 / \mathrm{s})$ & 0.02832 & cubic meter per second $\left(\mathrm{m}^{3} / \mathrm{s}\right)$ \\
\hline
\end{tabular}

International System of Units to U.S. customary units

\begin{tabular}{ccc}
\hline Multiply & By & To obtain \\
\hline \multicolumn{3}{c}{ Length } \\
\hline millimeter $(\mathrm{mm})$ & 0.03937 & inch (in.) \\
\hline
\end{tabular}




\section{Datum}

Vertical coordinate information is referenced to the North American Vertical Datum of 1988 (NAVD 88) or National Geodetic Vertical Datum of 1929 (NGVD 29).

Horizontal coordinate information is referenced to the North American Datum of 1983 (NAD 83).

Elevation, as used in this report, refers to distance above the vertical datum.

\section{Supplemental Information}

Water year is the 12-month period from 0ctober 1 through September 30 . The water year is designated by the year in which it ends.

\section{Abbreviations}

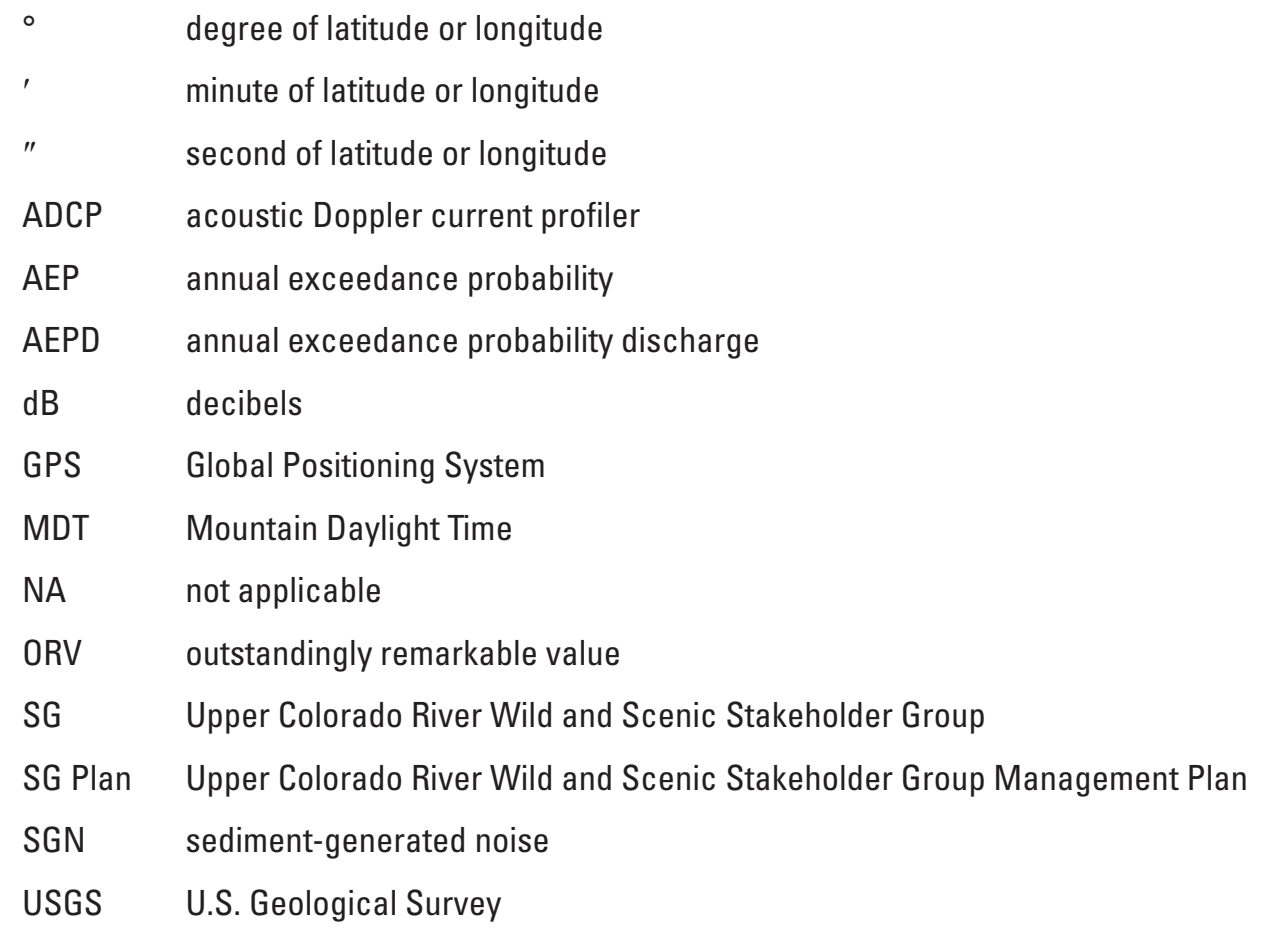

USGS U.S. Geological Survey 


\title{
Incipient Bed-Movement and Flood-Frequency Analysis using Hydrophones to Estimate Flushing Flows on the Upper Colorado River, Colorado, 2019
}

\author{
By Michael S. Kohn, Mathieu D. Marineau, Laura A. Hempel, and Richard R. McDonald
}

\section{Abstract}

In 2019, the U.S. Geological Survey, in cooperation with the Upper Colorado River Wild and Scenic Stakeholder Group, studied the magnitude and recurrence interval of streamflow (discharge) needed to initiate bed movement of gravel-sized and finer sediment in a segment of the Colorado River in Colorado to better understand sediment movement and its relation to flow regimes of the river. The study area extended from the confluence of the Blue and Colorado Rivers near Kremmling, Colorado, downstream to the confluence of the Eagle and Colorado Rivers near Dotsero, Colo. Bed movement occurred more frequently and at lower streamflows from State Bridge to Catamount Bridge compared to the study area upstream from State Bridge. As a result, the flushing flow was characterized in the study area using two definitions: the "upstream flushing flow" for locations above State Bridge and the "downstream flushing flow" for locations below State Bridge.

Acoustic data from stationary hydrophones continuously deployed in the spring and summer of 2019 and longitudinal hydrophone acoustic profiles manually collected in summer 2019 were used to identify the streamflow needed for incipient gravel-bed movement and establish flushing flows defined for this study. The upstream flushing flow was defined as 3,000 cubic feet per second $(\mathrm{ft} 3 / \mathrm{s})$ at streamgage 09058000 Colorado River near Kremmling, Colo. (the Kremmling streamgage) based on the underwater acoustic data from the downstream location at the Radium stationary site $\left(2,950 \mathrm{ft}^{3} / \mathrm{s}\right.$ at the Kremmling streamgage which was rounded to $3,000 \mathrm{ft} 3 / \mathrm{s}$ ). The downstream flushing flow was defined as 2,400 ft3/s at the Kremmling streamgage or 3,100 ft $3 / \mathrm{s}$ at streamgage 09060799 Colorado River at Catamount Bridge, Colo. (the Catamount Bridge streamgage) based on the more conservative streamflow associated with the flushing flow defined using underwater acoustic data from the downstream location at the above Catamount Bridge stationary site $(2,310 \mathrm{ft} 3 / \mathrm{s}$ at the Kremmling streamgage which was rounded to $2,400 \mathrm{ft}^{3} / \mathrm{s}$ and $3,040 \mathrm{ft} 3 / \mathrm{s}$ at the Catamount Bridge streamgage which was rounded to $\left.3,100 \mathrm{ft}^{3} / \mathrm{s}\right)$.
The annual series of peak-streamflow data at the Kremmling streamgage were used to estimate annual exceedance probability (AEP) streamflows to compare to the flushing flow. Results from the Denver Water Platte and Colorado Simulation Model were used to generate daily peak-streamflows for a future conditions scenario provided for this report. The upstream flushing flow of approximately $3,000 \mathrm{ft}^{3} / \mathrm{s}$ at the Kremmling streamgage has an AEP near 0.50 (2-year return period) depending on the period of historical record and an AEP near 0.43 (2.33-year return period) for the future period. The downstream flushing flow of approximately $2,400 \mathrm{ft}^{3} / \mathrm{s}$ at the Kremmling streamgage has an AEP near 0.67 (1.5-year return period) depending on the period of historical record and an AEP near 0.67 (1.5-year return period) for the future period.

\section{Introduction}

The ecologic function of mountain gravel-bed rivers depends on a full range of natural hydrologic conditions, including peak flows from the spring freshet that restore channel morphology and remove finer sediment from the gravel bed (Kondolf and Wilcock, 1996). Flushing flows restore or maintain aquatic habitat for macroinvertebrates and salmonids (salmon and trout) by removing fine sediment from riffles and pools used as rearing habitat and from gravel and cobble substrates used as spawning juvenile cover and improving invertebrate food production (Wilcock and others, 1996). Dams and water diversions, like those present in the upper Colorado River Basin, change the geomorphic function and relation with gravel beds by allowing the accumulation of fine sediment with deleterious effects on the salmonid population (Wilcock and others, 1996). Consequently, the occurrence of streamflows in the river basin of a magnitude sufficient to be classified as a flushing flow has become increasingly important to maintain a heathy ecosystem (Wilcock and others, 1996). In 2019, the U.S. Geological Survey (USGS), in cooperation with the Upper Colorado River Wild and Scenic Stakeholder Group (SG), studied the magnitude and recurrence interval of streamflow (discharge) 
needed to initiate bed movement of gravel-sized and finer sediment in a segment of the Colorado River to better understand sediment movement and its relation to flow regimes of the river. Additionally, the overall purpose was to better understand the streamflows required to maintain a healthy ecosystem and increase ecological function for salmonids in the upper Colorado River.

For this study, flushing flows are defined as the "streamflow needed to move gravel-sized or finer sediment in riffles to maintain spawning habitat for fish and maintain substrate and interstitial spaces for benthic macroinvertebrates" (SG, 2018, p. 6). The SG has negotiated the provisional flushing flow to be 2,000 cubic feet per second $\left(\mathrm{ft}^{3} / \mathrm{s}\right)$ at the USGS streamgage Colorado River near Kremmling, Colorado (USGS streamgage number 09058000; fig. 1; SG, 2012). The SG had reached a consensus on the definition of the flushing flow but had not evaluated the adequacy of the magnitude of the flushing flow in the study area (SG, 2018) or the recurrence interval of the streamflow in the river.

The SG Management Plan (SG Plan) was adopted by the Bureau of Land Management and the Forest Service on June 12, 2015 (SG, 2018). The aim of the SG Plan is to protect the outstandingly remarkable values (ORVs) previously identified by the Bureau of Land Management and the Forest Service for the Colorado River starting at its confluence with the Blue River, near Kremmling, Colo., to near Glenwood Springs, Colo. (SG, 2018). The SG Plan identified the ORVs in the study area as scenic, recreational fishing and floatboating, geological, wildlife, or historical (SG, 2012). Specifically, the stream-influenced recreational fishing and wildlife ORVs for the Colorado River are related to the magnitude and frequency of the flushing flows because flushing flows restore or maintain aquatic habitat, especially for salmonids (Ligon and others, 1995). The SG Plan was developed to monitor and protect the ORVs and is intended to serve as a Wild and Scenic Rivers management alternative for the resource management plan revision process (SG, 2018). An important benefit of the SG Plan is that, through the cooperative and voluntary efforts of interested east and west slope water users, local governments, state agencies, conservation organizations, and environmental, fishing, and float-boating interest groups, the ORVs can be protected and perhaps enhanced in ways that coordinate with Federal agency management (SG, 2012).

To better understand sediment movement and its relation to flow regimes of the Colorado River, the USGS used an innovative method to monitor incipient bed movement in the river by using hydrophones coupled with recording devices to collect underwater acoustic data at stationary hydrophone sites and along longitudinal profiles of the river during different streamflow conditions. The use of hydrophones to monitor incipient bed movement is an area of active USGS research, and the USGS has developed specialized recording devices that provide the data needed to address national issues relating to geomorphology, ecosystems, and flooding. The USGS previously used in situ and boat-mounted hydrophones to continuously monitor bed movement on the Trinity River in northern California (Marineau and others, 2016, 2017). This report expands on the research the USGS has carried out on the Trinity River by applying those techniques to improve the understanding of incipient bed movement and the relation to streamflow on the upper Colorado River. This approach uses deployed in situ and boat-mounted hydrophones to collect temporal and spatial underwater acoustic data that can be used to better understand geomorphic processes in gravel-bed rivers.

\section{Purpose and Scope}

The purpose of this report is to (1) summarize the methods used to estimate the magnitude and recurrence interval of the streamflow needed to initiate bed movement of gravel-sized and finer sediment in the upper Colorado River, (2) present study results of incipient bed-movement detection and its relation to streamflow, and (3) report the flood-frequency analyses based on historical data and a future conditions scenario. The study area was defined as the 67-mile (mi) reach of the Colorado River from the top of Gore Canyon near Kremmling, Colo, downstream to Dotsero, Colo., at the confluence with the Eagle River. This report presents an innovative method to monitor gravel-bed movement in riffles in the upper Colorado River using stationary hydrophones and a novel approach of conducting a longitudinal profile of the river to monitor incipient bed movement throughout the entire study area. Pebble counts of coarse surface particles were conducted in accordance with protocols established by Wolman (1954) and Bunte and Abt (2001) to provide general estimates of the size of the material that could be mobilized. Flood-frequency analyses were carried out using peak-streamflow data at the USGS streamgage Colorado River near Kremmling, Colo., from a variety of historical periods for comparison with a future conditions scenario. The scope of this report includes (1) describing data collection methods and an incipient bed-movement analysis to estimate the discharge of the flushing flow based on data from the USGS streamgage Colorado River near Kremmling, Colo. (fig. 1; table 1); (2) describing the recurrence interval of the flushing flow based on projected future water use at the USGS streamgage Colorado River near Kremmling, Colo.; and (3) describing additional data collection that could be used to further evaluate the flushing flow in this study area.

For this report, the flushing flow was defined as streamflow needed to initiate bed movement of gravel-sized and finer sediment in a segment of the Colorado River,

Figure 1 (following page). Map showing the locations of U.S. Geological Survey (USGS) streamgages and stationary hydrophone sites on the upper Colorado River, Colorado. (Colo., Colorado) 


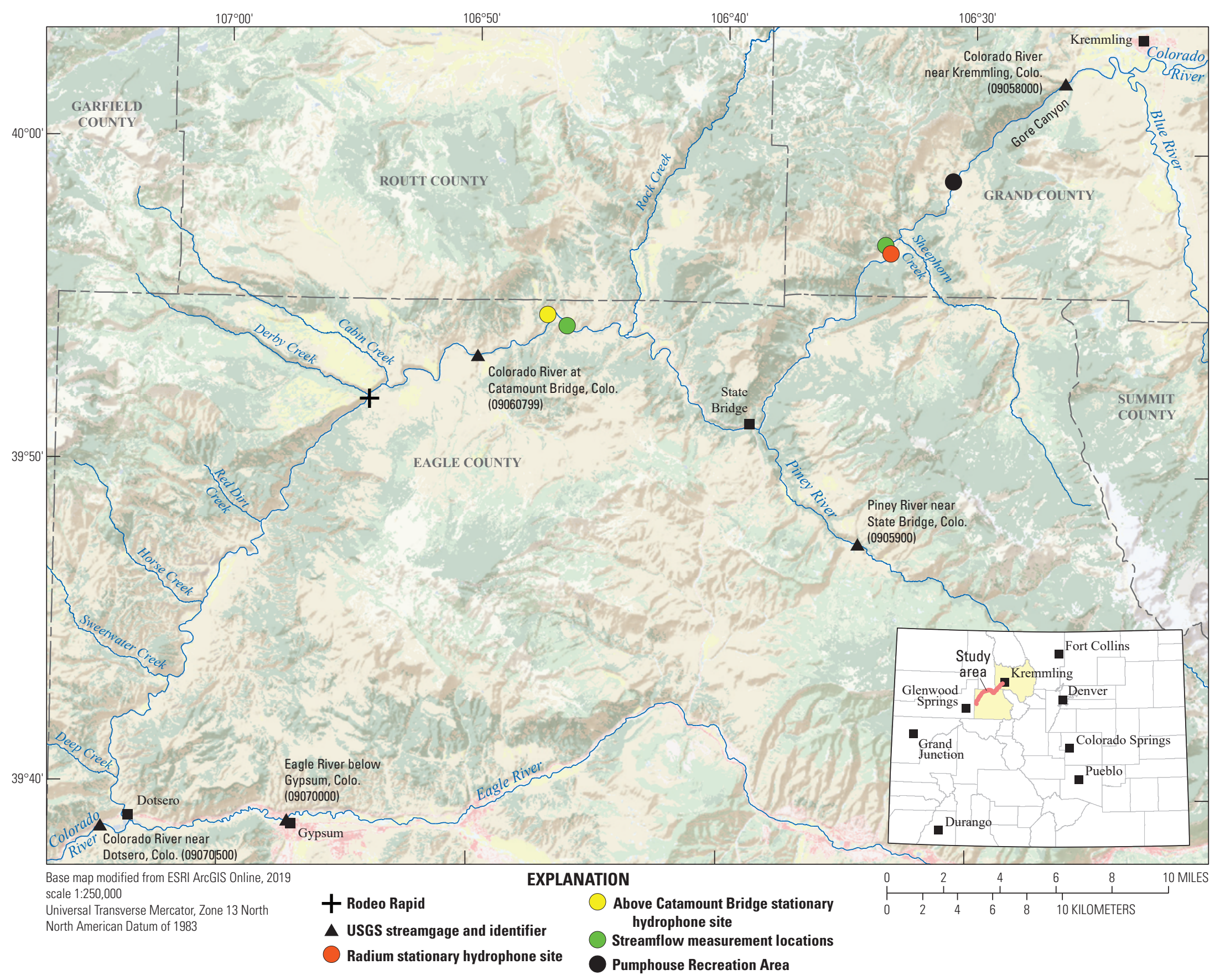


Table 1. Information about the U.S. Geological Survey (USGS) streamgages in the study area.

[Data are from the National Water Information System (https://doi.org/10.5066/F7P55KJN; U.S. Geological Survey, 2019a). ${ }^{\circ}$ degree of latitude or longitude; ', minute of latitude or longitude; ", second of latitude or longitude; Colo., Colorado; ft, foot; mi², square mile; NGVD29, National Geodetic Vertical Datum of 1929]

\begin{tabular}{lcccc}
\hline \multicolumn{1}{c}{$\begin{array}{c}\text { Streamgage } \\
\text { name }\end{array}$} & $\begin{array}{c}\text { Colorado River near } \\
\text { Kremmling, Colo. }\end{array}$ & $\begin{array}{c}\text { Colorado River at } \\
\text { Catamount Bridge, Colo. }\end{array}$ & $\begin{array}{c}\text { Eagle River below } \\
\text { Gypsum, Colo. }\end{array}$ & $\begin{array}{c}\text { Colorado River near } \\
\text { Dotsero, Colo. }\end{array}$ \\
\hline USGS streamgage number & 09058000 & 09060799 & 09070000 & 09070500 \\
Drainage area $\left(\mathrm{mi}^{2}\right)$ & 2,379 & 2,930 & 945 & 4,390 \\
Latitude & $40^{\circ} 02^{\prime} 12^{\prime \prime} \mathrm{N}$. & $39^{\circ} 53^{\prime} 27.96^{\prime \prime} \mathrm{N}$. & $39^{\circ} 38^{\prime} 58^{\prime \prime} \mathrm{N}$. & $39^{\circ} 38^{\prime} 40.60^{\prime \prime} \mathrm{N}$. \\
Longitude & $106^{\circ} 26^{\prime} 22^{\prime \prime} \mathrm{W}$. & $106^{\circ} 49^{\prime} 54.10^{\prime \prime} \mathrm{W}$. & $106^{\circ} 57^{\prime} 11^{\prime \prime} \mathrm{W}$. & $107^{\circ} 04^{\prime} 40.85^{\prime \prime} \mathrm{W}$. \\
$\begin{array}{l}\text { Period of record } \\
\quad \text { (water years1) }\end{array}$ & $\begin{array}{c}1905 \text { to } 1918 \text { and } 1962 \\
\text { to present [2019] }\end{array}$ & 2017 to present $[2019]$ & 1947 to present [2019] & 1941 to present [2019] \\
$\begin{array}{l}\text { County } \\
\text { Streamgage datum elevation }\end{array}$ & Grand & Eagle & Eagle & Eagle \\
$\quad$ (ft, NGVD29) & 7,320 & 6,540 & 6,275 & 6,130 \\
\hline
\end{tabular}

${ }^{1}$ Water year is the 12-month period from October 1 of one year through September 30 of the following year and is designated by the calendar year in which it ends.

which was defined by the study area. This report assumes that the detection of gravel movement was an indication that flushing flows had occurred. During 2019, bed movement was continuously monitored at two of five riffles where the SG had previously sampled for macroinvertebrates and collected cross-section and substrate data (SG, 2018). Data collected at the three other riffles during the acoustic longitudinal profiles also were examined. These riffles are additional examples of spawning gravels in the study area.

\section{Study Area Description}

The upper Colorado River study area was defined as the 67-mi reach of the Colorado River from the top of Gore Canyon near Kremmling, Colo., downstream to Dotsero, Colo., at the confluence with the Eagle River (fig. 1). The study area extended from the confluence of the Blue and Colorado Rivers near Kremmling, Colo., downstream to the confluence of the Eagle and Colorado Rivers near Dotsero, Colo. (fig. 1). The Colorado River near Kremmling, Colo., streamgage (USGS streamgage number 09058000), herein referred to as the "Kremmling streamgage," is located approximately at the upstream end of the study area (fig. 1; table 1); the Colorado River at Catamount Bridge, Colo., streamgage (USGS streamgage number 09060799), herein referred to as the "Catamount streamgage," is located approximately in the middle of the study area (fig. 1); and the Colorado River near Dotsero, Colo., streamgage (USGS streamgage number 09070500), herein referred to as the "Dotsero streamgage," is located approximately at the downstream end of the study area (fig. 1). Between the Kremmling and Dotsero streamgages, the average channel slope is $0.0034 \mathrm{foot}(\mathrm{ft}) / \mathrm{ft}$ or $18.2 \mathrm{ft} / \mathrm{mi}$ based on the elevations of the streamgages and the distance between the two streamgages along the river. Major tributaries that enter the Colorado River in the study area include Sheephorn Creek, Piney River, Rock Creek, Cabin Creek, Derby Creek, Red Dirt Creek, Horse Creek, Sweetwater Creek, and Deep Creek (fig. 1). Of the major tributaries, only the Piney River is currently (2019) gaged (Colorado Division of Water Resources, 2019; USGS, 2019a).

The upper Colorado River originates in northern and central Colorado and generally flows in a westerly direction through Kremmling, Colo., towards Dotsero, Colo., where it is joined by the Eagle River (fig. 1). The basin terrain is characterized by steep mountains, particularly in the most upstream parts of the basin. The upstream $5 \mathrm{mi}$ of the study area is exceptionally steep, not accessible by vehicle, and punctuated by multiple Class IV and V whitewater rapids. As a result, it is not suitable for data collection (Whitis and Vinson, 2017). The remaining $62 \mathrm{mi}$ of the study area are typical of a large mountain stream and consist of pools and riffles of varying sizes with the pools becoming larger and the riffles becoming less prevalent towards the lower part of the study area (Whitis and Vinson, 2017). Much of the streamflow in the basin upstream from the Kremmling streamgage is regulated with multiple large reservoirs by the agencies (Bureau of Reclamation, Colorado River Water Conservation District, Denver Water, and Northern Colorado Water Conservancy District) that operate the reservoirs and oversee transbasin diversions (Bureau of Reclamation, 2020; Denver Water, 2020). Conversely, most of the tributaries that enter the Colorado River in the study area are relatively unregulated. The greatest streamflows in the study area typically occur in late spring or early summer in response to the seasonal snowmelt. Figure 2 displays the hydrographs for the Dotsero, Catamount, and Kremmling streamgages. 


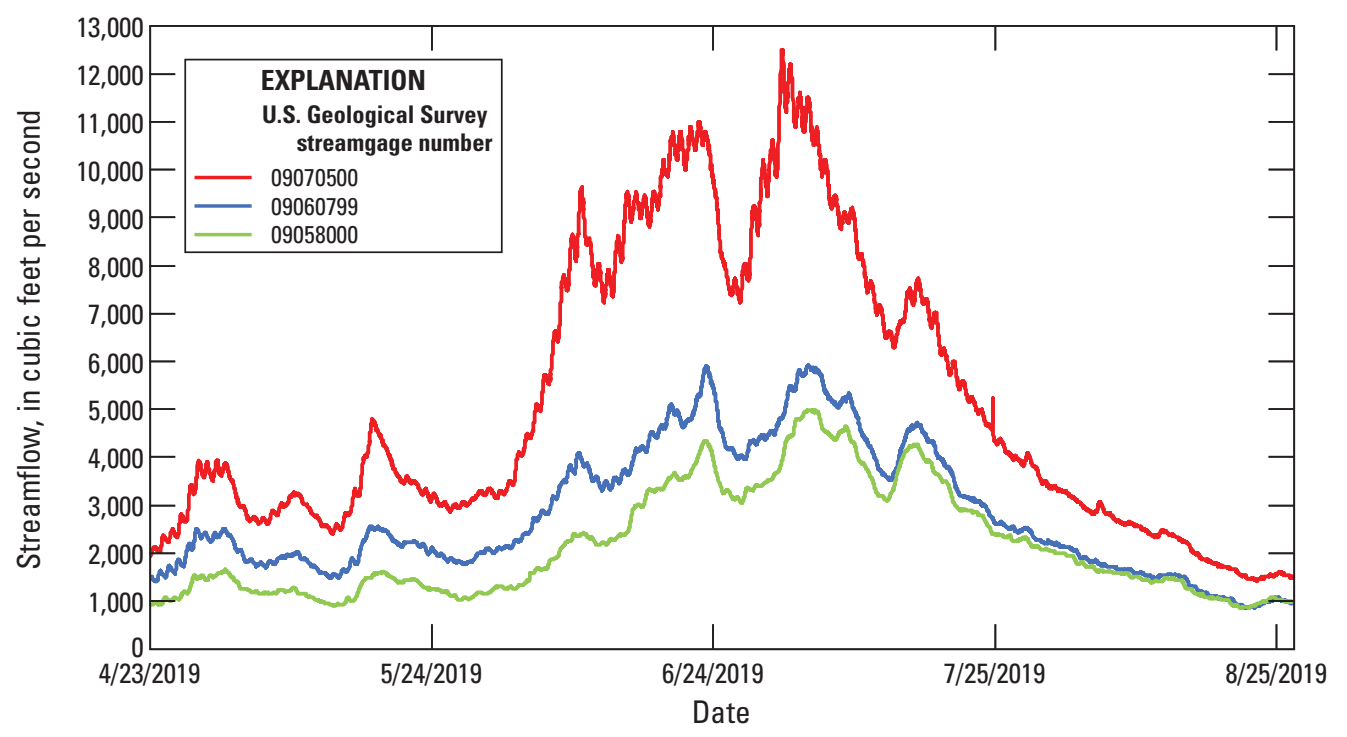

Figure 2. Graph showing streamflow recorded at 15-minute intervals at the Colorado River near Dotsero, Colorado, streamgage (U.S. Geological Survey [USGS] streamgage number 09070500); Colorado River at Catamount Bridge, Colo., streamgage (USGS streamgage number 09060799); and Colorado River near Kremmling, Colo., streamgage (USGS streamgage number 09058000) from April to August 2019.

\section{Previous Studies}

This section describes previous flushing-flow studies that were completed in the study area. Several studies have estimated the streamflow necessary to mobilize sediment in the study reach. Based on bedload-transport modeling, Grand County, Colorado (2010), recommended a flushing flow of $2,500 \mathrm{ft} 3 / \mathrm{s}$ with a 3 -day duration and frequency of once every 2 years for the Colorado River between Kremmling and the Eagle-Grand County line. Miller and Swaim (2011) analyzed the physical habitat in and adjacent to the Colorado River in the study area, determined the expected future impacts of streamflow alteration to the habitat, collected field data, and generated hydraulic and habitat models at three different sites. Miller and Swaim (2011) found that a range of streamflows, including a mixture of base flows $\left(500 \mathrm{ft}^{3} / \mathrm{s}\right.$ or greater), average peak flows $(2,000-4,000 \mathrm{ft} 3 / \mathrm{s})$, and greater peak flows (double the average peak flow), needed to occur one to two times every 10 years to maintain habitat in its current state. From a county-wide study of the Colorado River in Eagle County, Beeby and others (2014) estimated that the flushing flow generally exceeded $12,000 \mathrm{ft} 3 / \mathrm{s}$ at five study sites in the study area. Grain-size, hydraulic, and cross-section data were also collected at five locations by Beeby and others (2014). Beeby and Bledsoe (2015) performed additional analysis during the 2014 snowmelt runoff, which was one of the largest streamflow peaks in several decades. Beeby and Bledsoe (2015) concluded that, in general, the flushing flow was greater than $12,000 \mathrm{ft}^{3} / \mathrm{s}$ based on data collected during a large runoff year.
Hydrophones were first used to listen to sediment-generated noise (SGN) in the 1930s (Bedeus and Iviscics, 1964). Others have conducted laboratory and field experiments in attempts to correlate the acoustic signal to particle size and bed-movement rates (Thorne, 1985; Rouse, 1994; Barton and others, 2010). Hydrophone data have been used successfully as a surrogate to measure the volume of bedload sediment movement by calibrating the underwater noise magnitude with physical samples of bedload sediment volume of movement on the Trinity River, California (Marineau and others, 2016, 2017). Previously, longitudinal profiles of underwater acoustic data were collected with hydrophones on the Trinity River in California, the Gunnison River in Colorado, and the San Joaquin River in California; the data were used to determine the spatial variability of bed movement (Marineau and others, 2015).

\section{Methods}

Two independent and complementary lines of evidence were collected to detect incipient bed movement. First, two stationary hydrophone field sites were identified in March 2019 in collaboration with the SG based on river access, possible spawning riffles, and previous work; herein, these sites are referred to as the "Radium" and "above Catamount Bridge" sites (fig. 1). For redundancy, each site consisted of an upstream and a downstream monitoring reach location for a total of four stationary hydrophones at each site. The stationary hydrophone sites provided continuous time-series data of acoustic energy that served as a surrogate 
for bed-movement data at four stationary monitoring reach locations. Second, two longitudinal profiles were carried out at different streamflows to collect underwater acoustic data using boat-mounted hydrophones throughout the study area during a 2- to 3-day period. During the first of the two longitudinal profiles, an acoustic Doppler current profiler (ADCP) was used to measure streamflow at various locations throughout the study area to document streamflow accumulation. One of the limitations of the longitudinal profile hydrophone is that bed movement can occur in pulses, and when a hydrophone is placed on a mobile platform such as a boat, it may not be able to capture the spatial and temporal patterns of bed movement.

\section{Stationary Hydrophones}

Two stationary hydrophone systems, each with two independent hydrophones, were installed at each of the four monitoring reach locations (two at the Radium site and two at the above Catamount Bridge site); this resulted in eight hydrophones, four monitoring reach locations, and two sites. Two stationary hydrophone systems were installed April 23, 2019, at the above Catamount Bridge site and two were installed April 24, 2019, at the Radium site. These four systems recorded underwater sounds related to bed movement until they were removed on August 26, 2019. Two systems were installed to ensure that data collection would continue at each site (or reach) if equipment failed or was damaged. The upstream location and downstream location at the Radium site were located on the right streambank 400 $\mathrm{ft}$ and 2,000 ft downstream from the Grand County Road 11 Bridge, respectively (figs. 1 and 3). The upstream location and downstream location at the above Catamount Bridge site were located on the right streambank $16,800 \mathrm{ft}$ and $18,200 \mathrm{ft}$ upstream from the Catamount streamgage, respectively (figs. 1 and 4). Coordinates were obtained from a Global Navigation Satellite System survey of each of the four hydrophone locations and are described in table 2. The underwater acoustic data from the stationary hydrophones are available in Kohn and Hempel (2020).

\section{Stationary Underwater Acoustic Data Collection}

At each of the four monitoring reach locations (an upstream and downstream location at both sites), a stationary hydrophone system with two Aquarian H2a-XLR hydrophones and one recording computer was deployed. The stationary hydrophone systems were programmed to collect a 1-minute audio recording at 15-minute intervals, which is equivalent to the time stamp of the stage and streamflow data collected at the streamgages in the study area. The recording system was contained in a protective case (Pelican Products, Inc.) and secured to the streambank (fig. 5). Site visits occurred about every 4 to 6 weeks for routine servicing and downloading the latest data from the external memory Secure Digital card. During the site visits, the battery voltage was tested, the hydrophones were inspected (when conditions were wadable), and debris was removed. The sensitivity of the H2a-XLR hydrophones is -180 decibels $(\mathrm{dB})$ relative to 1 volt per pascal $( \pm-4 \mathrm{~dB})$ (Aquarian Audio, 2013). The preamplifier gain was set to $14 \mathrm{~dB}$, which provided a clear overall signal without clipping higher amplitude sounds.

At each of the four monitoring reach locations, two hydrophones were installed by attaching them to a $3-\mathrm{ft}$ long piece of steel rebar driven approximately $2 \mathrm{ft}$ into the streambed. Because it was expected that both hydrophones would be submerged during late spring and summer runoff, the first was attached approximately $1 \mathrm{ft}$ above the streambed, which was located at the water-surface elevation at the time of installation, and the second was located higher up on the streambank and attached about $1 \mathrm{ft}$ above the water surface at installation. A second piece of rebar was installed approximately $1 \mathrm{ft}$ directly upstream to help deflect debris that could otherwise accumulate on the hydrophone and result in sound transmission loss (fig. 5). The audio cable was routed

Table 2. Information on the four hydrophone monitoring reach locations at the two stationary hydrophone sites.

[ ${ }^{\circ}$, degree of latitude or longitude; ', minute of latitude or longitude; ", second of latitude or longitude; ft, foot; mi², square mile; NAVD 88, North American Vertical Datum of 1988]

\begin{tabular}{lcccc}
\hline $\begin{array}{c}\text { Location } \\
\text { name }\end{array}$ & $\begin{array}{c}\text { Upstream Radium } \\
\text { stationary hydrophone }\end{array}$ & $\begin{array}{c}\text { Downstream Radium } \\
\text { stationary hydrophone }\end{array}$ & $\begin{array}{c}\text { Upstream above Catamount } \\
\text { Bridge stationary } \\
\text { hydrophone }\end{array}$ & $\begin{array}{c}\text { Downstream above } \\
\text { Catamount Bridge } \\
\text { stationary hydrophone }\end{array}$ \\
\hline $\begin{array}{c}\text { Drainage area } \\
\left(\mathrm{mi}^{2}\right)^{1}\end{array}$ & 2,500 & 2,500 & 2,920 & 2,920 \\
$\begin{array}{l}\text { Latitude } \\
\text { Longitude }\end{array}$ & $39^{\circ} 57^{\prime} 04.94^{\prime \prime} \mathrm{N}$. & $39^{\circ} 56^{\prime} 53.28^{\prime \prime} \mathrm{N}$. & $39^{\circ} 54^{\prime} 40.90^{\prime \prime} \mathrm{N}$. & $39^{\circ} 54^{\prime} 29.62^{\prime \prime} \mathrm{N}$. \\
County & $106^{\circ} 33^{\prime} 31.19^{\prime \prime} \mathrm{W}$. & $106^{\circ} 33^{\prime} 21.90^{\prime \prime} \mathrm{W}$. & $106^{\circ} 47^{\prime} 07.67^{\prime \prime} \mathrm{W}$. & $106^{\circ} 47^{\prime} 03.39^{\prime \prime} \mathrm{W}$. \\
$\begin{array}{l}\text { Elevation (ft, } \\
\text { NAVD 88) }\end{array}$ & Grand & Grand & Eagle & Eagle \\
\hline
\end{tabular}

${ }^{1}$ From U.S. Geological Survey, 2019b. 


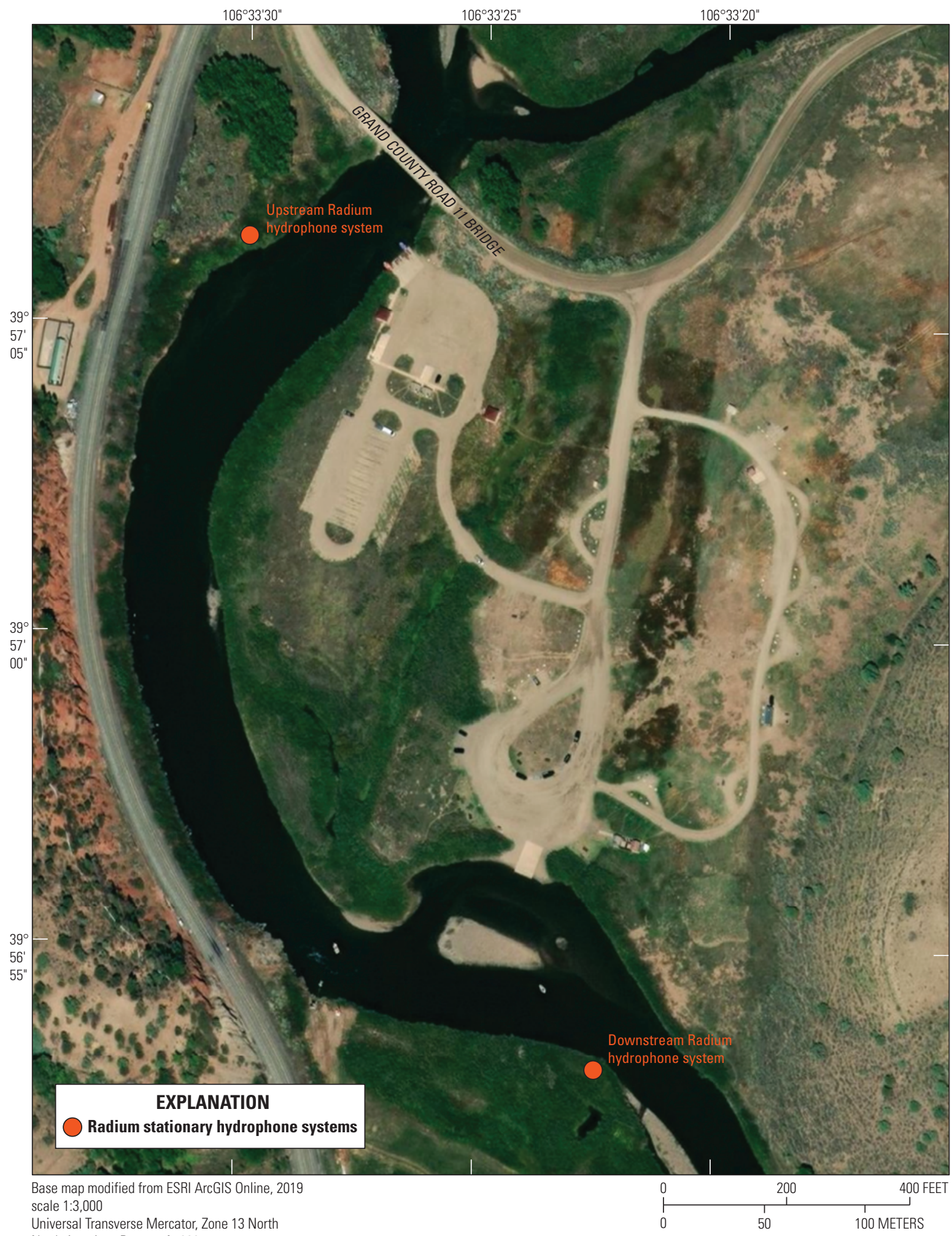

North American Datum of 1983

Figure 3. Map showing the stationary hydrophone monitoring reach locations at the Radium stationary hydrophone site. 


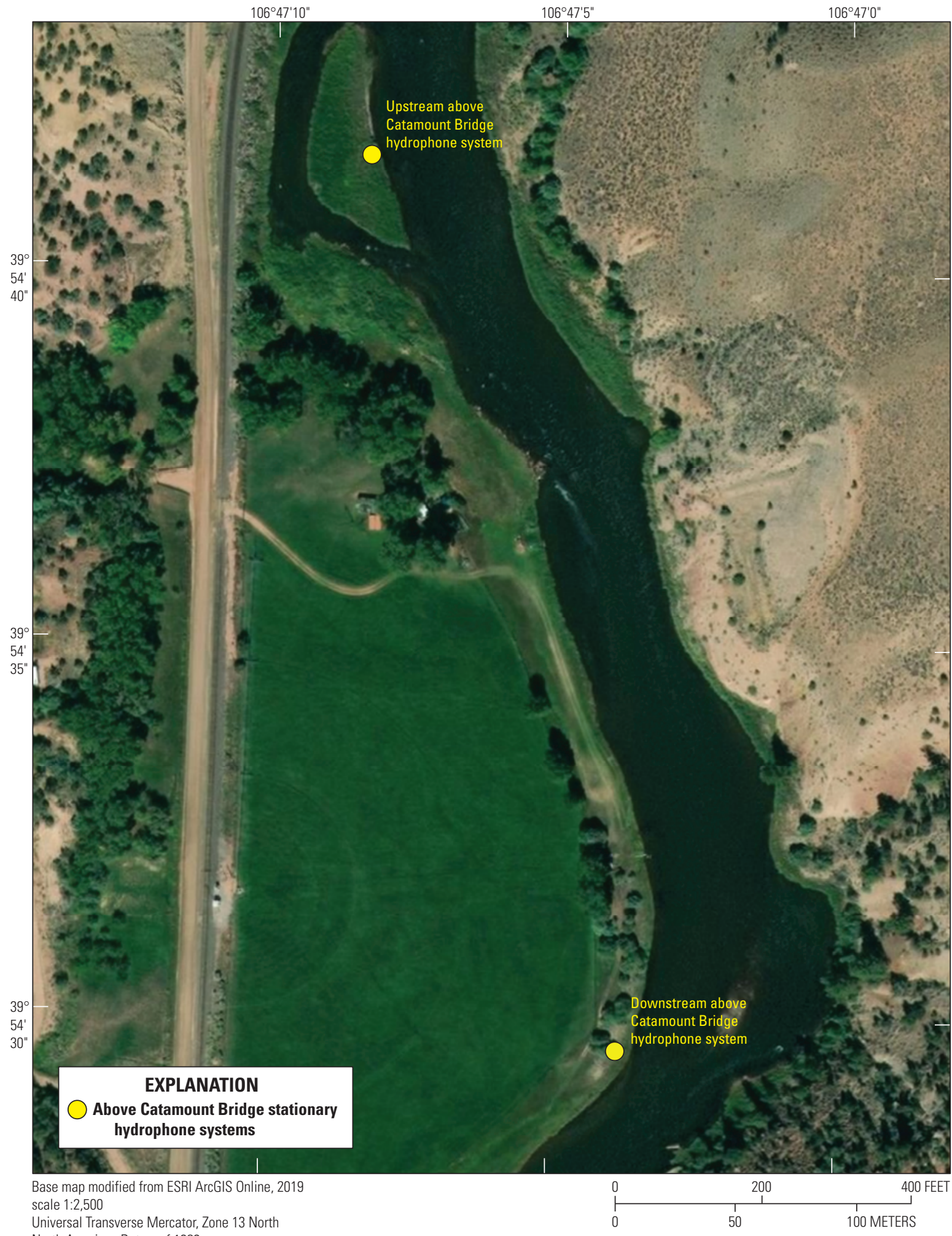

Figure 4. Map showing the stationary hydrophone monitoring reach locations at the above Catamount Bridge stationary hydrophone site. 

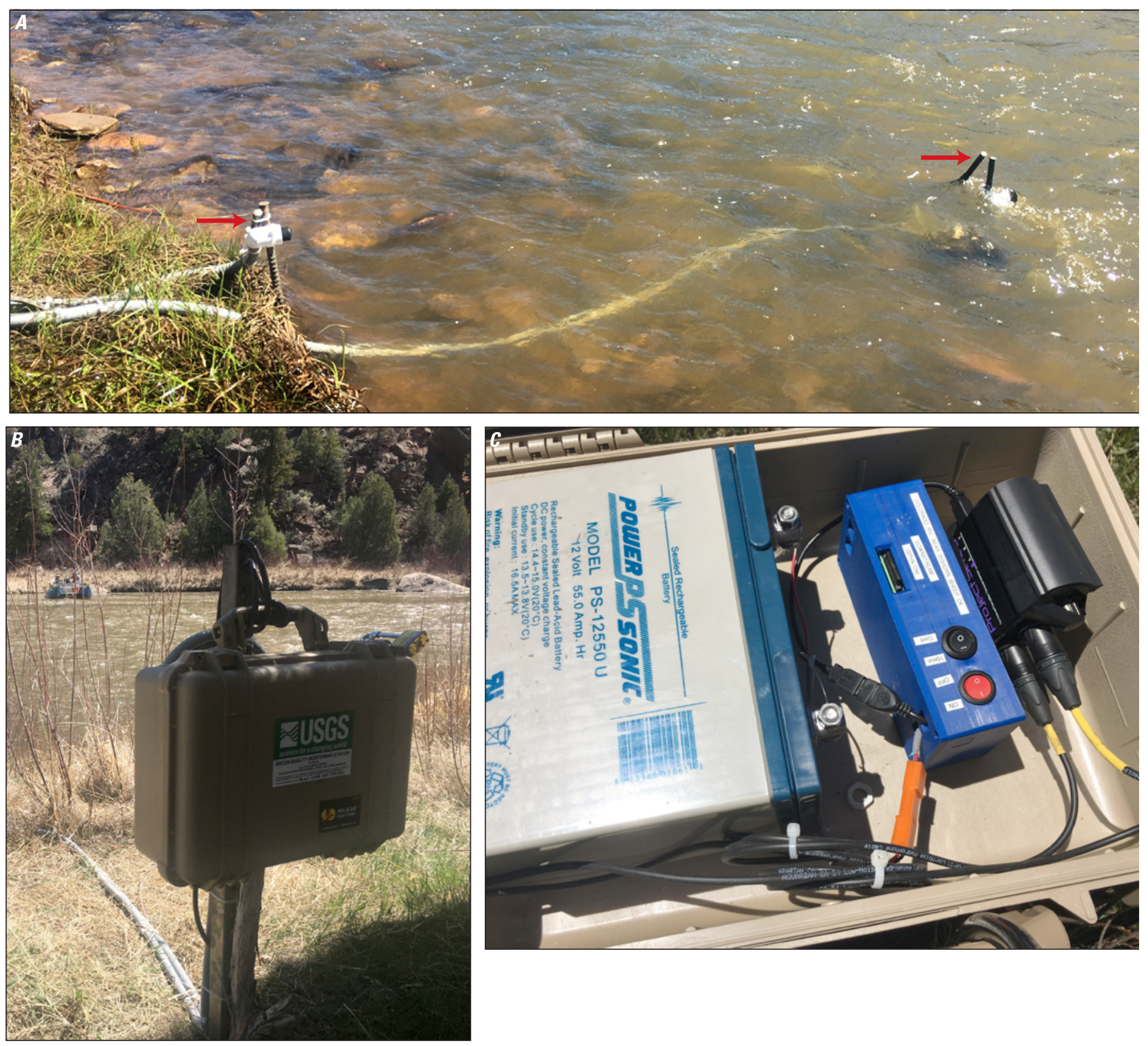

Figure 5. Photographs of the stationary hydrophone system. $A$, Photograph of hydrophones that were connected to flexible conduit as they were mounted in the streambed. The two additional pieces of rebar installed upstream from the two hydrophones to deflect debris are identified by the two red arrows. $B$, Photograph of the flexible conduit and protective case gage structure. $C$, Photograph showing the inside protective case gage structure that housed the battery used to supply power, data logger used to record and store data (blue case), and the pre-amplifier (black case) that converted the analog acoustic noise to a digital signal. (Photograph by Rob Buirgy, Colorado River Wild and Scenic Stockholder Group, June 6, 2019, used with permission.)

from the hydrophones to the protective case using a flexible polyvinyl chloride conduit. The polyvinyl chloride conduit was secured to the streambed and streambanks using several pieces of u-shaped rebar. Because of an internal memory card malfunction, no data were collected from May 3 to June 17, 2019, at the upstream location at the Radium site and from May 9 to June 18, 2019, at the upstream location at the above Catamount Bridge site.

\section{Stationary Underwater Acoustic Data Processing}

The audio data were recorded as 44.1 kilohertz, 16-bit stereo (2-channel) .wav files for 1 minute at 15-minute intervals. Debris was found on the hydrophones during each routine servicing. At the end of the deployment, it did not appear that any of the hydrophones had moved during the deployment. 
Typically, audio recordings are processed in MATLAB $\AA$ (version 2019b, ®The MathWorks, Inc.) by first transforming the signals from the time domain to the frequency domain using a short-time Fourier transform to obtain the power spectral density. A spectrogram is then generated where time is displayed on the $\mathrm{x}$-axis, frequency on the y-axis, and the sound level for any given frequency and time is represented by color. However, because of the consistent presence of background noise in the same frequency band as SGN, which was likely caused by debris, it was determined that a manual data processing approach would be needed. As a result, audio recordings were selected at associated streamflow values at $200-\mathrm{ft} 3 / \mathrm{s}$ intervals throughout the spring and summer of 2019 to define the rising and falling limbs of the snowmelt runoff hydrograph. Then, two hydrologists independently performed an aural review of the raw 1-minute audio recordings and categorized the recordings into four bed-movement regimes, defined in table 3 , following the language from an early visual-based sediment movement scale developed by Kramer (1935), who evaluated critical motion in a flume. The four bed-movement regimes are (1) no movement, (2) very low movement, (3) low movement, and (4) moderate movement. After each recording was assigned a bed-movement regime, the average streamflow on both the rising and falling limb of the hydrograph that corresponded to each bed-movement regime category was determined for each of the four hydrophone monitoring reach locations and used to define the flushing flow. The streamflow associated with the very low bed-movement regime corresponded to incipient bed movement and was too minor to perform the function of the flushing flow. The flushing flow was assigned as the average streamflow for the low bed-movement regime.
To assign streamflows to bed movement, the acoustic-data time stamp was matched with the nearest time stamp of the continuous streamflow record at the Kremmling streamgage and Catamount streamgage. Because of the complexities of time of travel between the stationary hydrophone sites and the streamgages, the most effective way to correlate the hydrophone underwater acoustic data to streamflow is to compare the exact same time stamps.

\section{Acoustic Longitudinal Profiles}

Two acoustic longitudinal profiles were carried out at different streamflows to collect underwater acoustic data using hydrophones throughout the study area on June 6-8, 2019 (June 6-8 longitudinal profile), and June 18-19, 2019 (June 18-19 longitudinal profile). Figures 6 and 7 summarize the streamflow recorded at 15 -minute intervals at USGS streamgages on the upper Colorado River during the June 6-8 and June 18-19 longitudinal profiles, respectively. The June 6-8 longitudinal profile began at the Pumphouse Recreation Area (fig. 1) and ended at the Dotsero boat launch located at Dotsero, Colo. (fig. 1). The June 18-19 longitudinal profile began at the Pumphouse Recreation Area (fig. 1) and ended at the Catamount Bridge boat launch located at the Catamount streamgage (fig. 1). During the June 6-8 longitudinal profile, two mobile hydrophone systems were deployed from two different rafts to collect SGN. During the June 18-19 longitudinal profile, one mobile hydrophone system was deployed on one raft to collect SGN. The underwater acoustic data collected using hydrophones from the longitudinal profiles are available in Kohn and Hempel (2020).

Table 3. Descriptions of the bed-movement regimes that were assigned at the Radium and above Catamount Bridge stationary hydrophone sites (modified from Kramer, 1935).

\begin{tabular}{ll}
\multicolumn{1}{c}{$\begin{array}{c}\text { Bed-movement } \\
\text { regime }\end{array}$} & Description \\
\hline No movement & $\begin{array}{l}\text { Quiet or only water noise; no detectable particle movement } \\
\text { Mostly quiet, with only a few (less than 5 distinct particles) heard during a 1-minute period; usually the record- } \\
\text { ing needs to be amplified to hear particle movement. } \\
\text { Multiple distinct particles (5-15) heard rolling or saltating nearby during a 1-minute period, with some } \\
\text { background noise from more particles in the distance; recording may need to be amplified to detect particle } \\
\text { movement. } \\
\text { Tow movement }\end{array}$ \\
Moderate movement & hear particle collisions.
\end{tabular}

Figure 6 (following page). Graphs showing streamflow recorded at 15-minute intervals during the June 6-8, 2019, longitudinal profile measured at the $A$, Colorado River near Kremmling, Colorado, streamgage (U.S. Geological Survey [USGS] streamgage number 09058000); $B$, Colorado River at Catamount Bridge, Colo., streamgage (USGS streamgage number 09060799); and $C$, Colorado River near Dotsero, Colo., streamgage (USGS streamgage number 09070500). 

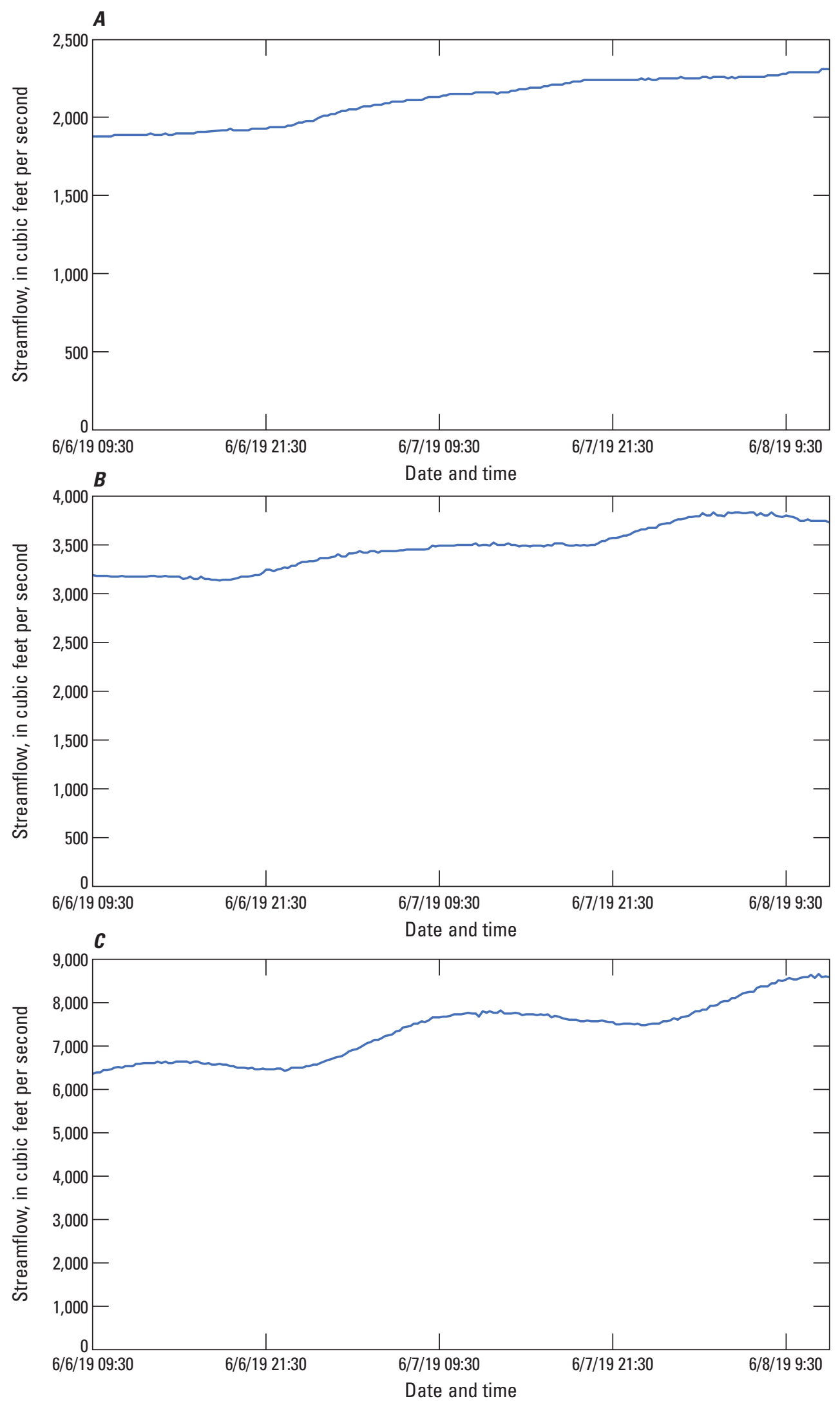

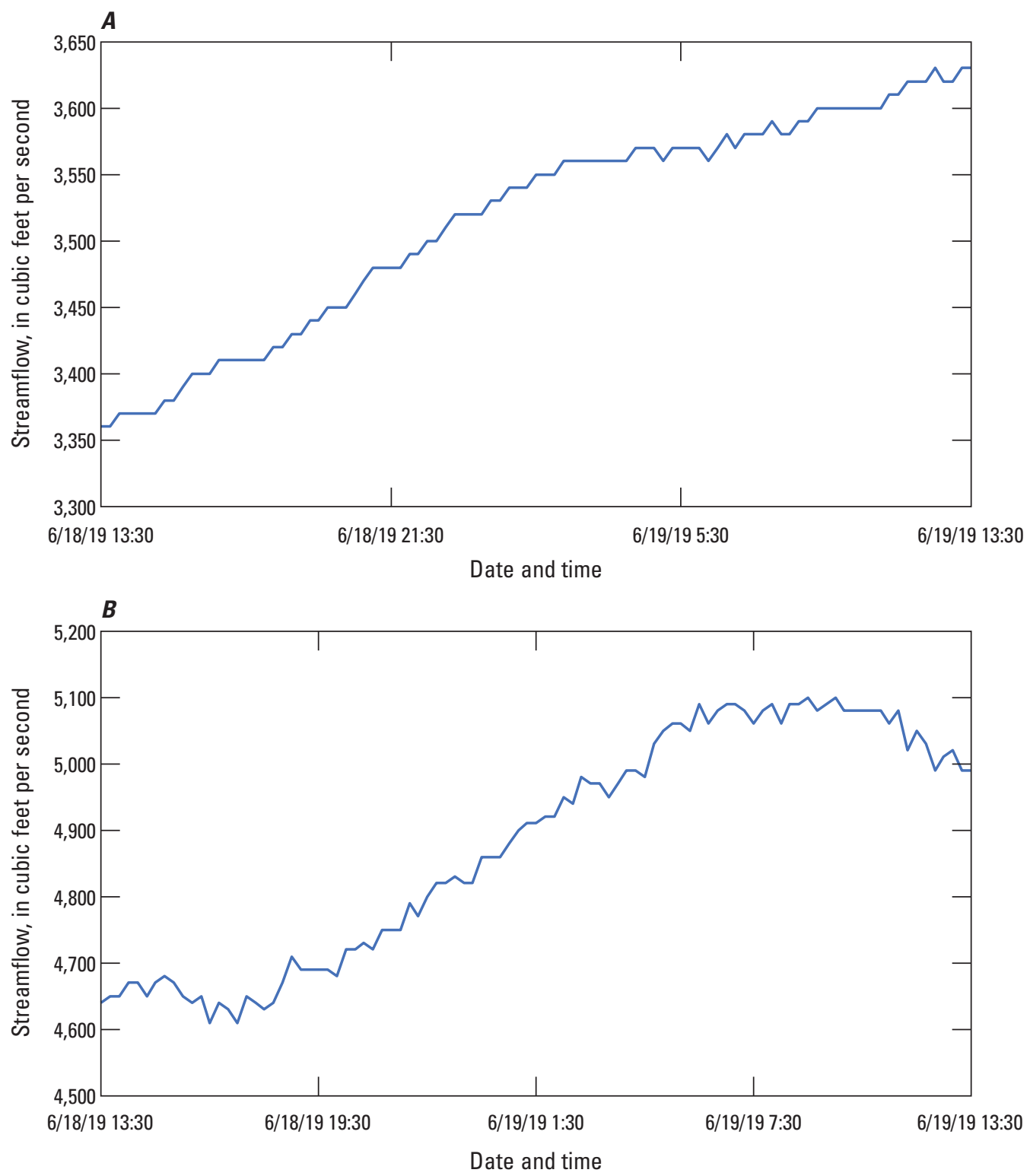

Figure 7. Graphs showing streamflow recorded at 15-minute intervals during the June $18-19,2019$, longitudinal profile measured at the $A$, Colorado River near Kremmling, Colorado, streamgage (U.S. Geological Survey [USGS] streamgage number 09058000) and B, Colorado River at Catamount Bridge, Colo., streamgage (USGS streamgage number 09060799).

\section{Longitudinal Underwater Acoustic Data Collection}

For the June 6-8 longitudinal profile, one of the mobile hydrophone systems, consisting of two H2a-XLR hydrophones (Aquarian Audio, 2013) and a recording system, was attached to a 16-ft Hyside inflatable raft and mounted $1 \mathrm{ft}$ below the water line. The first hydrophone was attached on the port side of the raft, and the second was attached on the starboard side of the raft. A second mobile hydrophone system, consisting of one H2a-XLR hydrophone (Aquarian
Audio, 2013) and a recording system, was attached to a $16-\mathrm{ft}$ Down River Equipment inflatable cataraft and mounted $1 \mathrm{ft}$ below the water line on the stern of the raft.

For the June 18-19 longitudinal profile, a mobile hydrophone system, consisting of two H2a-XLR hydrophones (Aquarian Audio, 2013) and a recording system, was attached to a 16- $\mathrm{ft}$ Hyside inflatable raft and mounted about $1 \mathrm{ft}$ below the water line. The first hydrophone was attached on the port side of the raft, and the second was attached on the starboard side of the raft. For both longitudinal profiles, audio data were recorded on the mobile recording system and saved to a Secure 
Digital card. A small MTK3339-based Global Positioning System (GPS) module, with an accuracy of less than $10 \mathrm{ft}$ according to the manufacturer (Adafruit Industries, 2020), was mounted to the small protective case. The GPS unit generated positioning data and a time stamp, which correlated to the audio data files. Audio was recorded continuously, and position was recorded at 1-second intervals throughout both longitudinal profiles. The boat typically floated near the thalweg (the middle, deepest point) of the river; therefore, oaring occurred only when necessary to minimize background noise generated by nonsediment. Figure 8 displays photographs of the mobile hydrophone system and ADCP deployment used for the longitudinal profiles.

\section{Longitudinal Acoustic Doppler Current Profiler Data Collection}

For the June 6-8 longitudinal profile, streamflow was measured using a Teledyne Marine RiverPro ADCP (Teledyne RD Instruments, 2014), and the bed movement was monitored using the mobile hydrophone system (fig. $8 A$ ). The location of the ADCP was determined using a Trimble R8 model 3 GPS (Trimble Navigation Limited, 2009), which is a differential GPS with a horizontal resolution of generally less than $3.28 \mathrm{ft}$, that was mounted on a mast directly above the ADCP and secured to the bow of a 16-ft Down River Equipment inflatable cataraft (fig. $8 B$ ). Both the ADCP data and the GPS data were collected using the Teledyne Marine WinRiver II computer software (Teledyne Marine, 2019). Three streamflow measurements were made following the procedures in Mueller and others (2013) and Mueller (2016) to determine the streamflow that occurred during the June 6-8 longitudinal profile. On the afternoon of June 7, the computer that was used for ADCP data collection failed at Rodeo Rapid (fig. 1). Subsequently, no ADCP data were collected downstream from that point. ADCP data were not collected during the June 18-19 longitudinal profile.

\section{Longitudinal Underwater Acoustic Data Processing}

The longitudinal underwater acoustic data collected using hydrophones were first plotted in a spectrogram, which indicated that near-continuous noise was present in the lower frequencies (less than 6 kilohertz) throughout the entire profile. Aural review of the audio recordings suggested that the source was not SGN, but water noise likely generated by either the rafts or the paddle movement. The SGN frequency was determined to range from 6 to 22 kilohertz based on analysis of the spectrogram and aural review of multiple audio recordings at various locations and from various days. This frequency range excludes most of the ambient noise except for some noise created by the interaction between the boat and water or oaring motions, actions that only occurred when required to move the vessel safely through rapids. This nonsediment background noise was not substantial compared to the SGN.

The decibel level from the hydrophones was used to establish a threshold between when bed movement was present and when bed movement was not present. An aural review of the underwater acoustic data throughout the full spectrum of decibels determined that a threshold of $93 \mathrm{~dB}$ was appropriate for the presence versus absence of bed movement associated with the longitudinal underwater acoustic data collected with hydrophones from the 16-ft Hyside inflatable raft. A similar analysis was conducted for the 16-ft Down River Equipment inflatable cataraft, and a threshold of $86 \mathrm{~dB}$ was established. Different thresholds were determined because different hydrophones were deployed, and the raft configurations differed.

River centerline stationing, which is defined for this report as a continuous line starting at the receiving water body that generally follows the middle of the channel, was delineated during typical low-flow periods; the stationing measures distance along the centerline. For this report, river centerline stationing was established based on $3.28-\mathrm{ft}$ spacing beginning at the confluence with the Eagle River, and generally followed the middle of the channel as delineated during typical low-flow periods. The cumulative distance along the centerline path was then estimated for each river station. The GPS coordinates from the longitudinal underwater acoustic data were snapped to the nearest 3.28 -ft spaced river station in the Esri ArcGIS software (https://www.esri.com/ software/arcgis/). Because longitudinal underwater acoustic data from the 16-ft Hyside inflatable raft were spatially coincident with longitudinal underwater acoustic data from the 16-ft Down River Equipment inflatable cataraft during the June 6-8 longitudinal profile, comparisons could be drawn between the two longitudinal hydrophone profiles and the longitudinal underwater acoustic data.

\section{Longitudinal Acoustic Doppler Current Profiler Processing}

The ADCP data were processed using the USGS software program QRev, in accordance with Mueller (2016). The QRev program applies common and consistent computational algorithms combined with automated filtering and quality assessment of the data to improve the quality and efficiency of streamflow measurements and helps ensure that USGS streamflow measurements are consistent, accurate, and independent of the manufacturer of the instrument used to make the measurement (Mueller, 2016). These measurements were compared to and were corroborated by streamflow data recorded at the USGS streamgages in the study area (USGS, 2019a). 

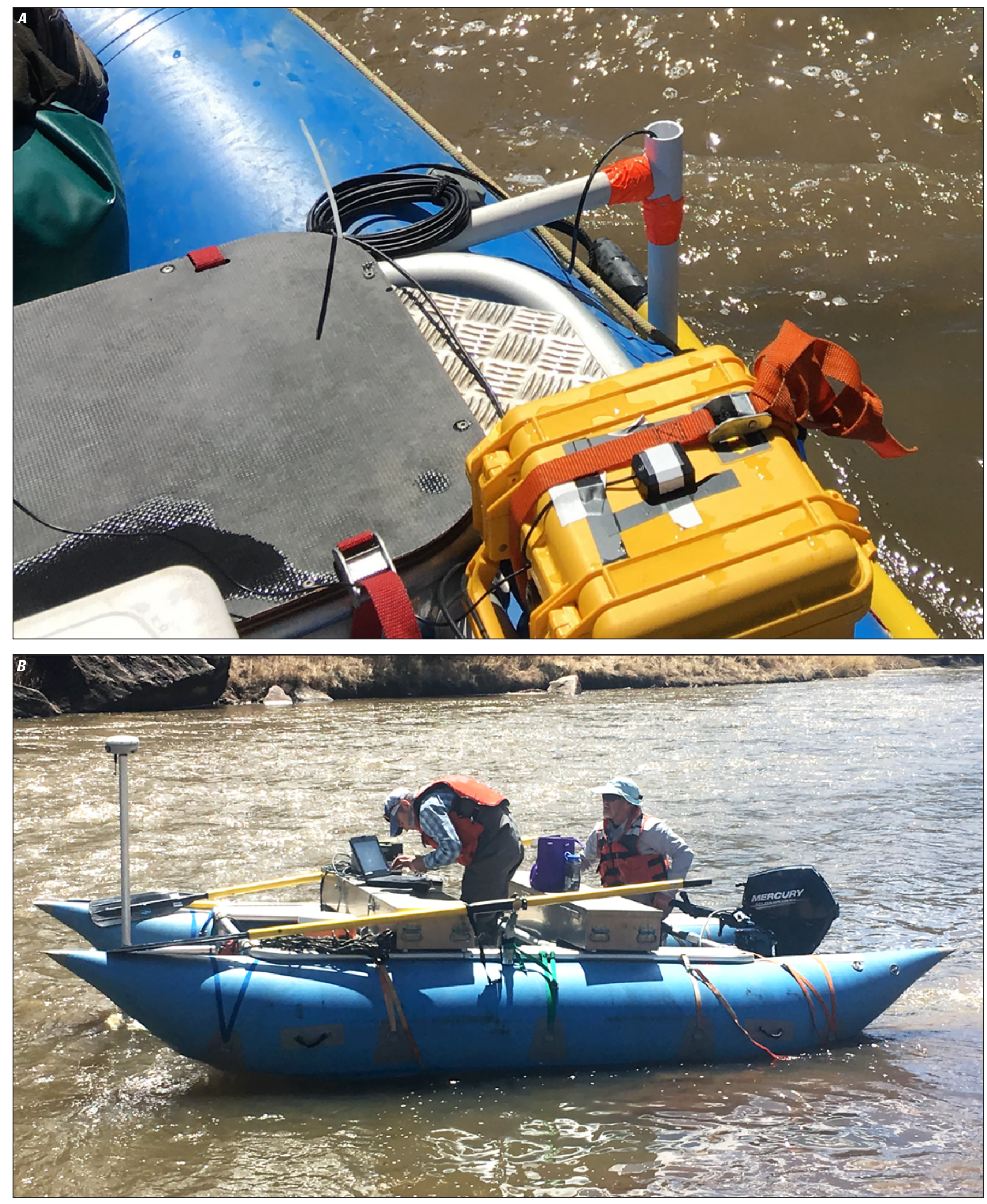

Figure 8. Photographs of the $A$, mobile hydrophone system and $B$, acoustic Doppler current profiler deployment used for the longitudinal profiles. 


\section{Pebble Counts}

Pebble counts of coarse surface particles were performed in the wadeable areas adjacent to the stationary hydrophones to provide general estimates of the size of the material that could be mobilized and recorded near the hydrophones. At each sampling location, 100 particles were selected from underneath the toe of the sampler's boot during a random walk and were measured using a gravelometer, in accordance with protocols established by Wolman (1954) and Bunte and Abt (2001). More precise sampling approaches, such as a systematic grid pattern or increasing the number of pebbles sampled to 400 , were not adopted because the pebble counts were intended to explore only general differences in surface particle sizes and potential bed material at stationary hydrophone sites (Bunte and Abt, 2001). Furthermore, because of high and sustained streamflows during the study, the sampling area was constrained to wadeable areas adjacent to the stationary hydrophones, which precluded more robust and spatially distributed sampling methods. Two pebble count samples were collected at the Radium stationary hydrophone site (fig. 3) on April 24, 2019. The sample sites were located (1) within a 150-ft, wadeable radius surrounding the upstream Radium stationary hydrophone system, on an eddy bar; and (2) on the subaerial exposed (not under water) gravel island located approximately $220 \mathrm{ft}$ northwest of the downstream Radium stationary hydrophone system, on a detached point bar. Two pebble count samples were also collected at the above Catamount Bridge stationary hydrophone site (fig. 4) on April 23, 2019. The sampling sites were located (1) within a $150-\mathrm{ft}$, wadeable radius surrounding the upstream above Catamount Bridge stationary hydrophone system, adjacent to a riffle; and (2) within a 150 -ft, wadeable radius surrounding the downstream above Catamount Bridge stationary hydrophone system, adjacent to a riffle.

The pebble count samples were processed by measuring the particle size of the intermediate axis (B-axis) with a gravelometer, and the largest bin size the particle did not pass through (the retaining sieve size) was recorded. Each of the pebble size measurements were compiled into retaining-sieve size classes. The retaining-sieve size was then converted into the passing-sieve size to calculate the percentage of particles per size class, and the latter was used to calculate the cumulative percent finer and generate particle size distribution curves. Lastly, equation 2.15b from Bunte and Abt (2001) was used to estimate the D16 (16th percentile grain size), D50 (50th percentile, or median, grain size), and D84 (84th percentile grain size) values. The pebble count data are available in Kohn and Hempel (2020).

\section{Flood-Frequency Analysis}

The annual series of peak-streamflow data at the Kremmling streamgage was used to estimate annual exceedance probability discharges (AEPDs) to compare to an estimate of the flushing-flow discharge, such as the 2-year flood discharge. Peak-streamflow data at the Kremmling streamgage are published in USGS (2020). The estimated AEPDs for the Kremmling streamgage were computed using the USGS software program PeakFQ version 7.2 (Veilleux and others, 2014). The PeakFQ program automates the Expected Moments Algorithm and Multiple Grubbs-Beck test procedure described in Bulletin 17C (England and others, 2019). The AEPDs were determined using systematic water year data from seven different time periods between water year 1982 and water year 2019 (October 1, 1981, through September 30, 2019). These seven different time periods were chosen by the SG to provide context on the possible range of AEPDs at the Kremmling streamgage. This report expresses flood-frequency estimates in terms of annual exceedance probability (AEP), which is the reciprocal of the recurrence interval. For example, a 2-year flood discharge is the same as a discharge having a $0.50 \mathrm{AEP}$; this flood discharge also is described as a 50-percent flood or Q50\% (Southard and Veilleux, 2014).

For this report, the log-Pearson Type III frequency distribution was fit to the logarithms of the annual-peak streamflows to determine flood-frequency estimates following the guidelines established in Bulletin 17C (England and others, 2019). The average, standard deviation, and skew coefficients were used to fit the distribution to describe the mid-point, slope, and curvature of the flood-frequency curve, respectively (Gotvald and others, 2012). Streamgage skew was combined or weighted with a generalized value that was derived from a generalized or weighted skew map, which is included in Bulletin 17B (Interagency Advisory Committee on Water Data, 1982). The weighted skew used in the analysis for this report was determined by weighting the streamgage skew and the regional skew and is inversely proportional to their respective mean square errors. The Expected Moments Algorithm retains the essential structure and moments-based approach of the existing Bulletin 17B procedures (Interagency Advisory Committee on Water Data, 1982) to determine flood frequency, but accommodates interval data to simplify the analysis of datasets containing censored observations, historical data, low outliers, and data points with high and low uncertainties common in paleofloods, and also provides enhanced confidence intervals for the AEPDs (England and others, 2019). The Multiple Grubbs-Beck test is a generalization of the Grubbs-Beck method that creates the standard procedure for recognizing multiple potentially influential low flows (Cohn and others, 2013). Additional information on flood-frequency analysis can be found in Bulletin 17B (Interagency Advisory Committee on Water Data, 1982), Eash and others (2013), Kohn and others (2016), and Bulletin 17C (England and others, 2019). 
Daily average streamflow results from the Denver Water Platte and Colorado Simulation Model ${ }^{1}$ were provided for this report (Jason Marks, Denver Water, written commun., January 9, 2020) and used to generate daily peak-streamflows for a future conditions scenario. The future conditions scenario included daily average streamflow values from the Denver Water Platte and Colorado Simulation Model for 45 years of hydrologic data from water years 1947 through 1991 at the Kremmling streamgage. Then, changes to the streamflows resulting from future water diversion projects (including the Windy Gap and Moffat Tunnel expansion projects [American Society of Civil Engineers, 2020; Northern Colorado Water Conservancy District, 2020]) that affect the annual peak streamflow were applied to the hydrologic data and as a result the future conditions scenario does not represent conditions during a specific time period but rather conditions that may result from future water diversion projects. The estimated AEPDs for the future streamflow conditions at the Kremmling streamgage were computed using the USGS software program PeakFQ and follow the same methods discussed earlier in this section.

\section{Incipient Bed-Movement Analysis}

Acoustic data, from stationary hydrophones (fig. 1) continuously deployed during spring and summer 2019, and longitudinal hydrophone acoustic profiles manually collected in summer 2019, were used to identify the streamflow needed for incipient gravel-bed movement and therefore determine the lower threshold for flushing flows as defined for this study. In addition, the flood-frequency analyses provide context on how often the streamflows mentioned in this section have occurred historically.

\section{Detection of Gravel-Bed Movement Based on Stationary Hydrophones}

The streamflows that initiated incipient motion of the gravel bed and established the flushing flow referenced to Kremmling and Catamount streamgages (USGS, 2019a) were identified independently by two hydrologists (table 4). Table 4 displays the range of average streamflows based on all four bed-movement regimes observed at the four stationary hydrophone monitoring reach locations and provides context regarding the variability between the categories. The flushing flows, as represented by the average streamflow at each streamgage for the low bed-movement regime category, between the Radium (approximately $3,000 \mathrm{ft} 3 / \mathrm{s}$ at the Kremmling streamgage) and above Catamount Bridge stationary hydrophone sites (approximately 2,000 ft3/s at the Kremmling streamgage) are noticeably different and

\footnotetext{
1Data from Denver Water are not available or have limited availability owing to restrictions (proprietary interest).
}

provide evidence that more than one flushing flow occurs in the study area. One possible limitation of the data collected at the upstream Radium stationary hydrophone system was a large eddy that was present on June 18 during the June 18-19 longitudinal profile. The eddy had not been present at the upstream Radium stationary hydrophone system site when the site was selected because flows were lower at that time. The eddy likely caused the data collected at this location to be unrepresentative of riffles in the study area because the horizontal range of the stationary underwater acoustic data may not have extended past the eddy. The distance into the stream that hydrophones can collect SGN is unknown, but the existence of a large eddy at the deployment location may have limited the data collection to the eddy.

\section{Longitudinal Profiles}

The 15-minute streamflows observed at each of the streamgages located in the upper Colorado River Basin at the beginning and end dates of the two acoustic longitudinal profiles are summarized in table 5. Underwater acoustic data were collected using hydrophones from the Pumphouse Recreation Area to the Dotsero boat launch (located at Dotsero, Colo.) during the June 6-8 longitudinal profile and from the Pumphouse Recreation Area to Catamount Bridge boat launch (located at the Catamount streamgage) during the June 18-19 longitudinal profile (fig. 1).

\section{Longitudinal Hydrophones}

Maps of the locations where bed movement was detected and not detected were generated for the June 6-8 longitudinal profile (fig. 9) and for the June 18-19 longitudinal profile (fig. 10). These data are also available in Kohn and Hempel (2020). Table 6 summarizes the percentage of data points where the bed movement was detected in various reaches (based on known locations in the study area) during the June 6-8 and June 18-19 longitudinal profiles. At the Radium stationary hydrophone site during the June 6-8 longitudinal profile, bed movement was only detected near the Grand County Road 11 Bridge and approximately $200 \mathrm{ft}$ upstream from the downstream Radium hydrophone system (fig. 11A). At the Radium stationary hydrophone site during the June 18-19 longitudinal profile, bed movement was detected everywhere except for a short reach a few hundred feet upstream from the downstream Radium hydrophone system (fig. 11B). At the above Catamount Bridge stationary hydrophone site during the June 6-8 longitudinal profile, bed movement was detected at the upstream and downstream hydrophone systems but not in a part of the reach between the hydrophone systems (fig. 12A). At the above Catamount Bridge stationary hydrophone site during the June 18-19 longitudinal profile, bed movement was indicated by all the collected data (fig. 12B). However, data from the middle of the reach are missing because the mobile hydrophone system 
Table 4. The average and range of average streamflows at the Colorado River near Kremmling, Colorado, streamgage 09058000 (Kremmling streamgage) and Colorado River at Catamount Bridge, Colo., streamgage 09060799 (Catamount streamgage) for the different bed-movement regime categories that were assigned at the four stationary hydrophone monitoring reach locations.

[The flushing flow was assigned as the average streamflow for the low bed-movement regime and is in bold. $\mathrm{ft} 3 / \mathrm{s}$, cubic feet per second]

\begin{tabular}{|c|c|c|c|c|}
\hline \multirow[b]{2}{*}{$\begin{array}{l}\text { Stationary hydrophone monitoring reach location } \\
\text { and bed-movement regime category }\end{array}$} & \multicolumn{4}{|c|}{ Average and range of streamflow for each bed-movement regime category } \\
\hline & $\begin{array}{l}\text { Average streamflow, } \\
\text { Kremmling streamgage } \\
\left(\mathrm{ft}^{3} / \mathrm{s}\right)\end{array}$ & $\begin{array}{c}\text { Average streamflow, } \\
\text { Catamount streamgage } \\
(\mathrm{ft} 3 / \mathrm{s})\end{array}$ & $\begin{array}{c}\text { Streamflow range, } \\
\text { Kremmling streamgage } \\
\left(\mathrm{ft}^{3} / \mathrm{s}\right)\end{array}$ & $\begin{array}{c}\text { Streamflow range, } \\
\text { Catamount streamgage } \\
\left(\mathrm{ft}^{3} / \mathrm{s}\right)\end{array}$ \\
\hline \multicolumn{5}{|l|}{ Upstream Radium stationary hydrophone ${ }^{1}$} \\
\hline No movement & 2,120 & 2,330 & $2,120-2,120$ & $2,330-2,330$ \\
\hline Very low movement & 3,130 & 3,700 & $3,120-3,140$ & $3,460-3,940$ \\
\hline Low movement & 3,280 & 4,100 & $3,230-3,330$ & $3,880-4,310$ \\
\hline Moderate movement & 3,320 & 3,820 & 13,320 & 23,820 \\
\hline \multicolumn{5}{|l|}{ Downstream Radium stationary hydrophone } \\
\hline No movement & 2,100 & 2,910 & $2,080-2,120$ & $2,570-3,250$ \\
\hline Very low movement & 2,270 & 3,010 & $2,150-2,390$ & $2,980-3,030$ \\
\hline Low movement & 2,950 & 3,700 & $2,650-3,250$ & $3,250-4,160$ \\
\hline Moderate movement & 3,140 & 4,060 & $3,050-3,220$ & $4,020-4,090$ \\
\hline \multicolumn{5}{|l|}{ Upstream above Catamount Bridge stationary hydrophone ${ }^{3}$} \\
\hline No movement & 1,440 & 1,880 & $1,320-1,550$ & $1,820-1,930$ \\
\hline Very low movement & 1,680 & 2,360 & $1,510-1,840$ & $2,350-2,380$ \\
\hline Low movement & 1,790 & 2,420 & $1,490-2,080$ & $2,340-2,500$ \\
\hline Moderate movement & 2,810 & 3,170 & $2,750-2,870$ & $3,110-3,240$ \\
\hline \multicolumn{5}{|l|}{ Downstream above Catamount Bridge stationary hydrophone } \\
\hline No movement & 1,460 & 2,030 & $1,420-1,500$ & $1,990-2,080$ \\
\hline Very low movement & 1,680 & 2,530 & $1,590-1,770$ & $2,500-2,560$ \\
\hline Low movement & 2,310 & 3,040 & $2,160-2,460$ & $2,990-3,100$ \\
\hline Moderate movement & 3,240 & 4,020 & $2,880-3,600$ & $3,890-4,150$ \\
\hline
\end{tabular}

1Only one recording was identified in this regime.

${ }^{2}$ No data were collected from May 3 to June 17, 2019, so much of the data analysis was based on descending hydrograph limb.

3 No data were collected from May 9 to June 18, 2019, so much of the data analysis was based on descending hydrograph limb. 
Table 5. Streamflow observed at the U.S. Geological Survey (USGS) streamgages in the study area during the acoustic longitudinal profiles.

[The range represents the 15-minute streamflow at the beginning and end of the acoustic longitudinal profiles from USGS, 2019a. The streamflow at the Eagle River below Gypsum, Colorado, streamgage was subtracted from the streamflow at the Colorado River near Dotsero, Colo., streamgage, so it could be compared to the other Colorado River streamgages. $\mathrm{ft}^{3}$ /s, cubic feet per second; NA, not applicable because the June 18-19, 2019, longitudinal profile ended at Colorado River at Catamount Bridge, Colo., streamgage (09060799)]

\begin{tabular}{lcc}
\hline \multicolumn{1}{c}{ USGS streamgage and identifier } & \multicolumn{2}{c}{ Date } \\
\cline { 2 - 3 } & \multicolumn{1}{c}{ June 6-8, 2019 } & June 18-19, 2019 \\
\hline Colorado River near Kremmling, Colo. (09058000) & $1,880 \mathrm{ft} 3 / \mathrm{s}-2,310 \mathrm{ft} 3 / \mathrm{s}$ & $3,340 \mathrm{ft} 3 / \mathrm{s}-3,630 \mathrm{ft} / \mathrm{s}$ \\
Colorado River at Catamount Bridge, Colo. (09060799) & $3,190 \mathrm{ft} 3 / \mathrm{s}-3,730 \mathrm{ft} 3 / \mathrm{s}$ & $4,630 \mathrm{ft} 3 / \mathrm{s}-4,990 \mathrm{ft} 3 / \mathrm{s}$ \\
Piney River near State Bridge, Colo. (09059500) & $626 \mathrm{ft}^{3} / \mathrm{s}-679 \mathrm{ft} 3 / \mathrm{s}$ & $667 \mathrm{ft} 3 / \mathrm{s}-685 \mathrm{ft} 3 / \mathrm{s}$ \\
Eagle River below Gypsum, Colo. (09070000) & $2,980 \mathrm{ft} 3 / \mathrm{s}-4,200 \mathrm{ft} 3 / \mathrm{s}$ & $\mathrm{NA}$ \\
Colorado River near Dotsero, Colo. (09070500) & $6,350 \mathrm{ft} 3 / \mathrm{s}-8,580 \mathrm{ft} 3 / \mathrm{s}$ & $\mathrm{NA}$ \\
Colorado River near Dotsero, Colo. (09070500) minus & $3,370 \mathrm{ft} 3 / \mathrm{s}-4,380 \mathrm{ft} 3 / \mathrm{s}$ & $\mathrm{NA}$ \\
\hline Eagle River below Gypsum, Colo. (09070000) & & \\
\hline
\end{tabular}

was pulled out of the water to head for shore. An aural review of the data on either side of the data gap indicated that bed movement was likely present in the data gap.

The SG previously sampled for macroinvertebrates, collected cross-section data, and collected substrate data at three other riffles in the study area (Beeby and others 2014; SG, 2018). These riffles are additional examples of spawning gravels in the study area, and data collected at these riffles during the acoustic longitudinal profiles were examined. At the riffle near the Pumphouse Recreation Area (SG, 2018), no bed movement was detected on June 6, 2019, at 10:00 am Mountain Daylight Time (MDT; fig. 13A) when the streamflow at the Kremmling streamgage was $1,880 \mathrm{ft} 3 / \mathrm{s}$; however, bed movement was detected on June 18, 2019, at 1:30 pm MDT (fig. 13B) when the streamflow at the Kremmling streamgage was $3,340 \mathrm{ft} 3 / \mathrm{s}$ (USGS, 2019a). At the riffle near State Bridge (SG, 2018), no bed movement was detected on June 6, 2019, at 4:00 pm MDT (fig. 14A) when the streamflow at the Kremmling streamgage was $1,890 \mathrm{ft} 3 / \mathrm{s}$; however, bed movement was detected on June 19, 2019, at 08:45 am MDT (fig. 14B) when the streamflow at the Kremmling streamgage was 3,570 ft3/s (USGS, 2019a). At the riffle below Red Dirt Creek (SG, 2018), bed movement was detected on June 8, 2019, at 10:00 am MDT (fig. 15) when the streamflow at the Kremmling streamgage was $2,290 \mathrm{ft} 3 / \mathrm{s}$, the streamflow at the Catamount streamgage was $3,780 \mathrm{ft} 3 / \mathrm{s}$, and the streamflow at the Dotsero streamgage minus the streamflow at the Eagle River below Gypsum, Colo., streamgage (USGS streamgage number 09070000) was 4,220 ft3/s (USGS, 2019a). Data were not collected at the riffle below Red Dirt Creek that was identified by the SG (SG, 2018) on the June 18-19 longitudinal profile.

Table 6. Summary of the percentage of data points where bed movement was detected in reaches of the upper Colorado River during the June 6-8, 2019, and June 18-19, 2019, longitudinal profiles.

[NA; not applicable]

\begin{tabular}{lcc}
\hline \multicolumn{3}{c}{ Percentage of data points where bed movement was detected } \\
\hline \multicolumn{1}{c}{ Reach } & June 6-8, 2019 & June 18-19, 2019 \\
\hline Pumphouse Recreation Area to the State Bridge & 18 & 49 \\
Pumphouse Recreation Area to the Catamount streamgage & 37 & 67 \\
Pumphouse Recreation Area to the Dotsero boat launch & 48 & NA \\
State Bridge to the Catamount streamgage & 31 & 88 \\
State Bridge to the Dotsero boat launch & 60 & NA \\
Catamount streamgage to the Dotsero boat launch & 62 & NA \\
\hline
\end{tabular}

Figure 9 (following page). Map showing where bed movement was detected (in brown or red) or was not detected (in green or blue) during the June 6-8, 2019, longitudinal profile. Because two different hydrophone types were used, a threshold of 93 decibels was used upstream from the Lyons Gulch boat launch, and a threshold of 86 decibels was used downstream from the Lyons Gulch boat launch. (Colo., Colorado; USGS, U.S. Geological Survey) 


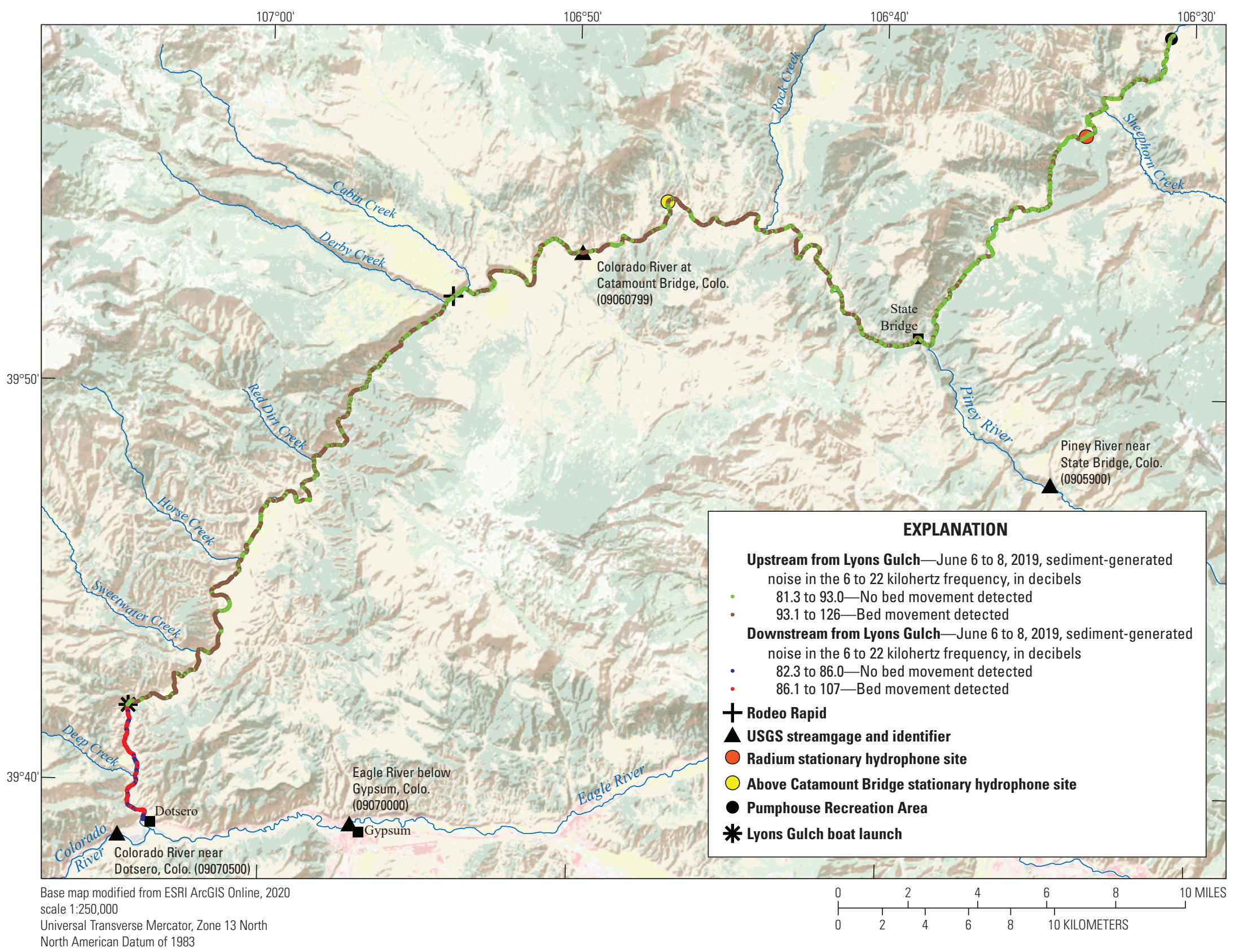




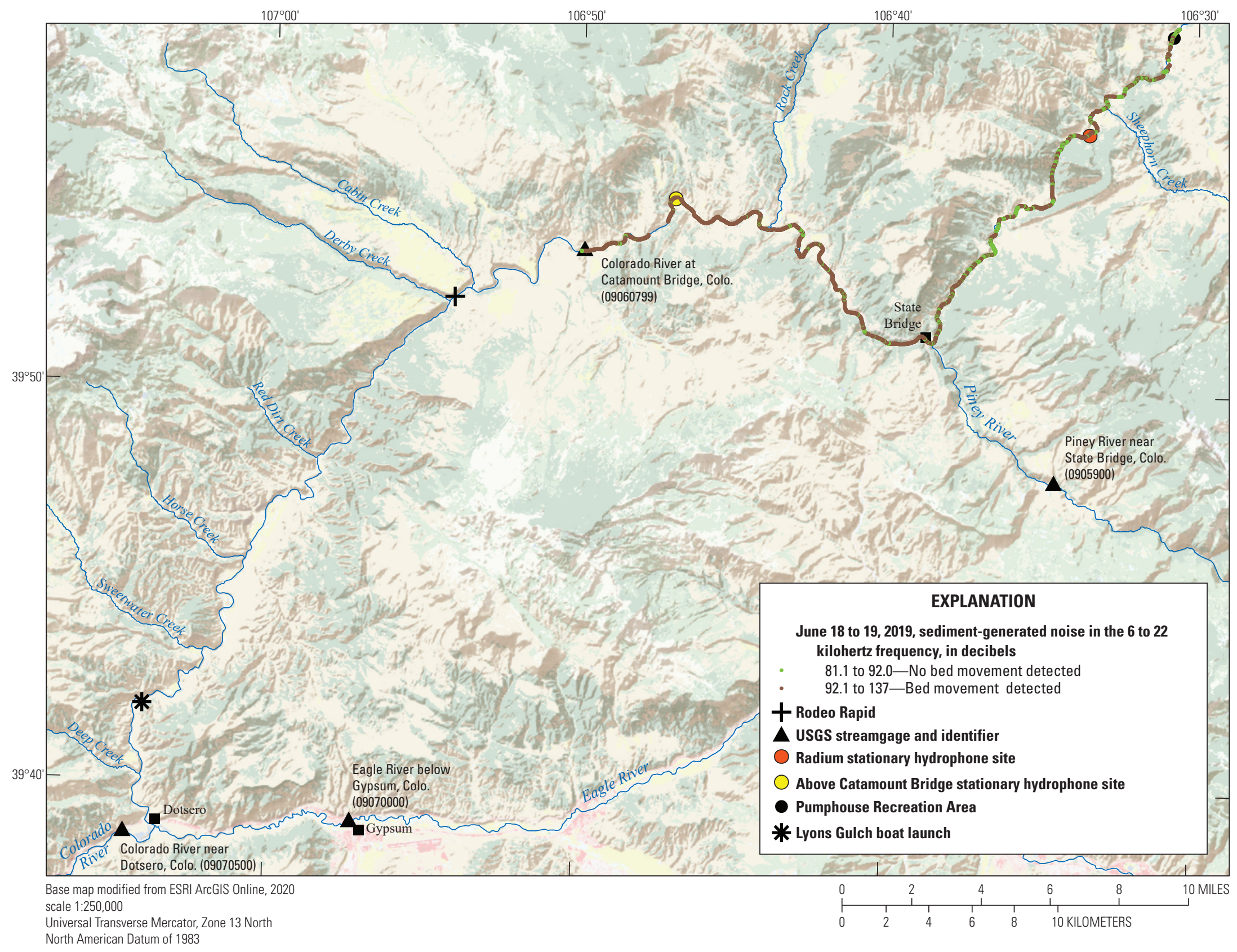

Figure 10. Map showing where bed movement was detected (in brown) or was not detected (in green) during the June 18-19, 2019, longitudinal profile. (Colo., Colorado; USGS, U.S. Geological Survey) 


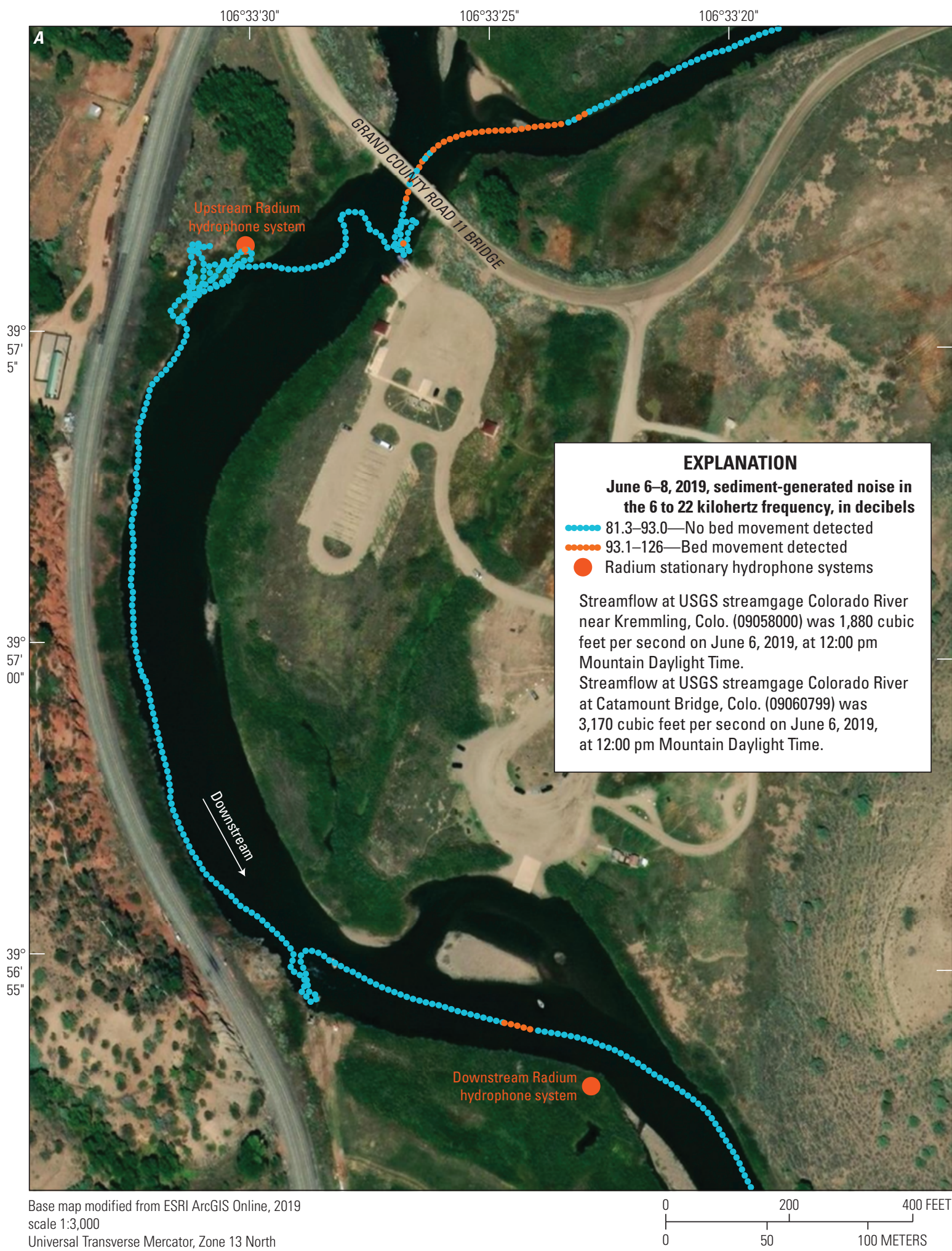

Figure 11. Maps showing where bed movement was detected (in orange) or was not detected (in blue) at the Radium stationary hydrophone monitoring reach locations during the $A$, June 6-8, 2019, and $B$, June 18-19, 2019, longitudinal profiles. (Colo., Colorado; USGS, U.S. Geological Survey) 


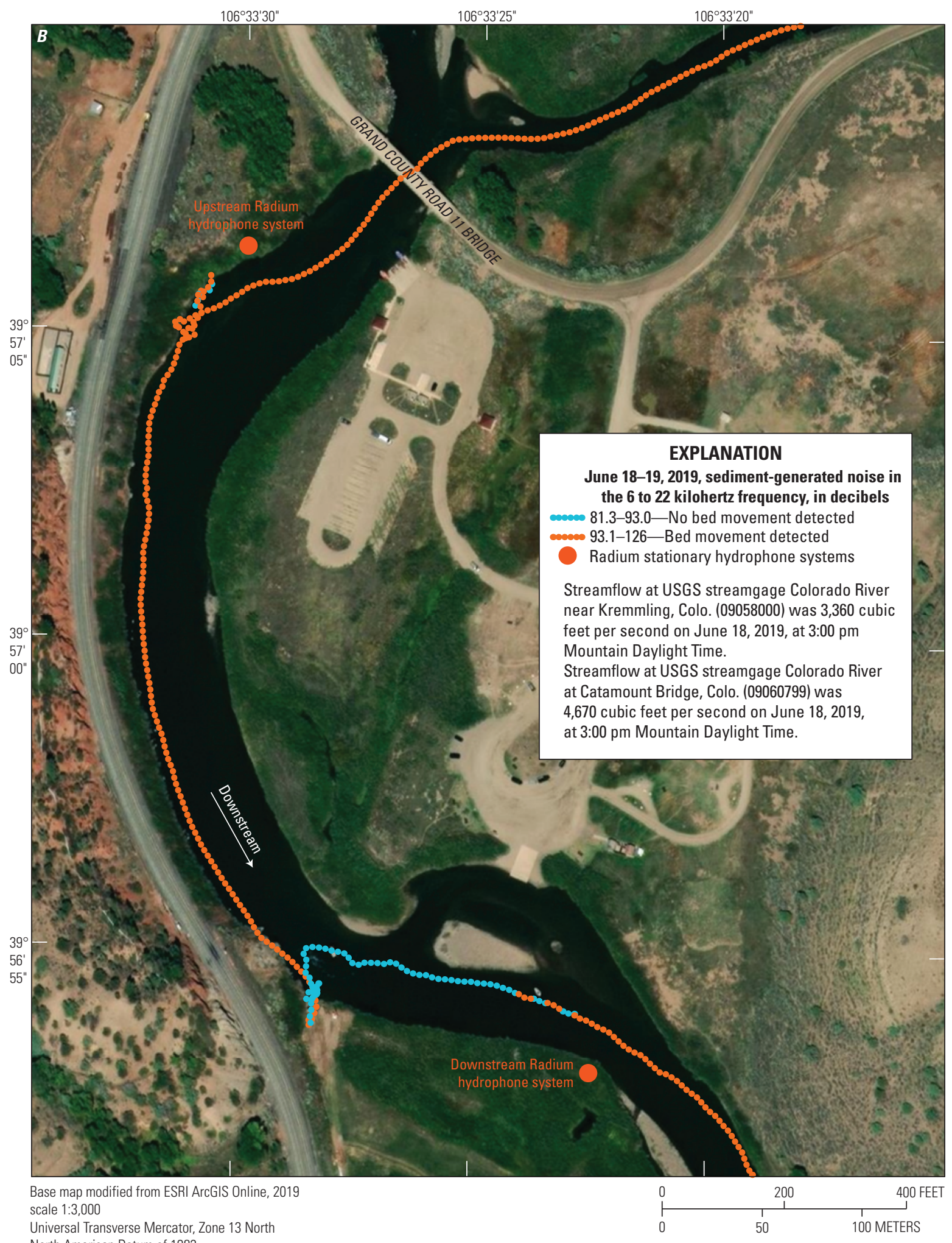

Figure 11. - Continued 


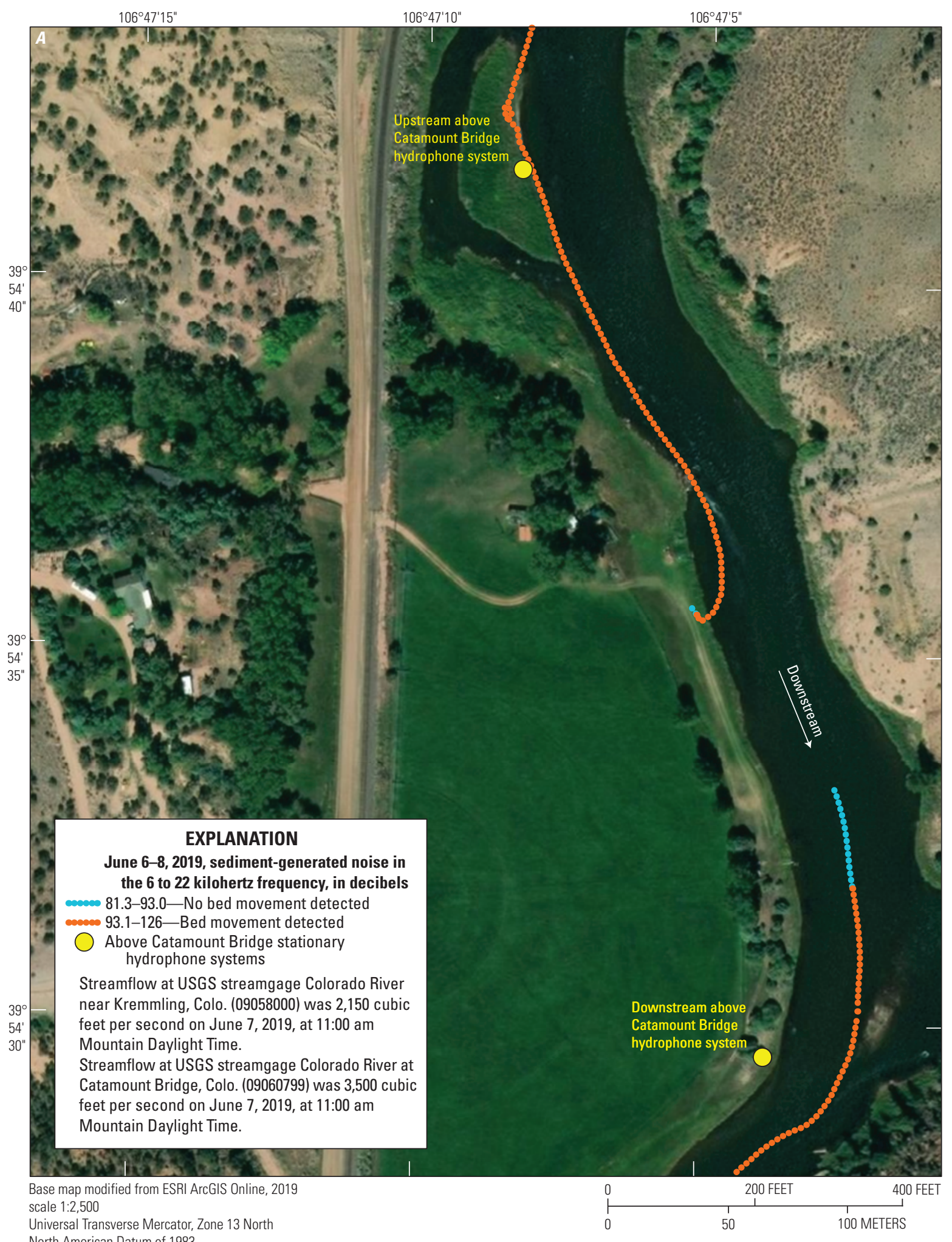

Figure 12. Maps showing where bed movement was detected (in orange) or was not detected (in blue) at the above Catamount Bridge stationary hydrophone monitoring reach locations during the $A$, June $6-8,2019$, and $B$, June 18-19, 2019, longitudinal profiles. Data from the middle of the reach are missing because the mobile hydrophone system was pulled out of the water to head for shore. However, an aural review of the data on either side of the data gap indicated that bed movement was likely present in the data gap (Colo., Colorado; USGS, U.S. Geological Survey) 


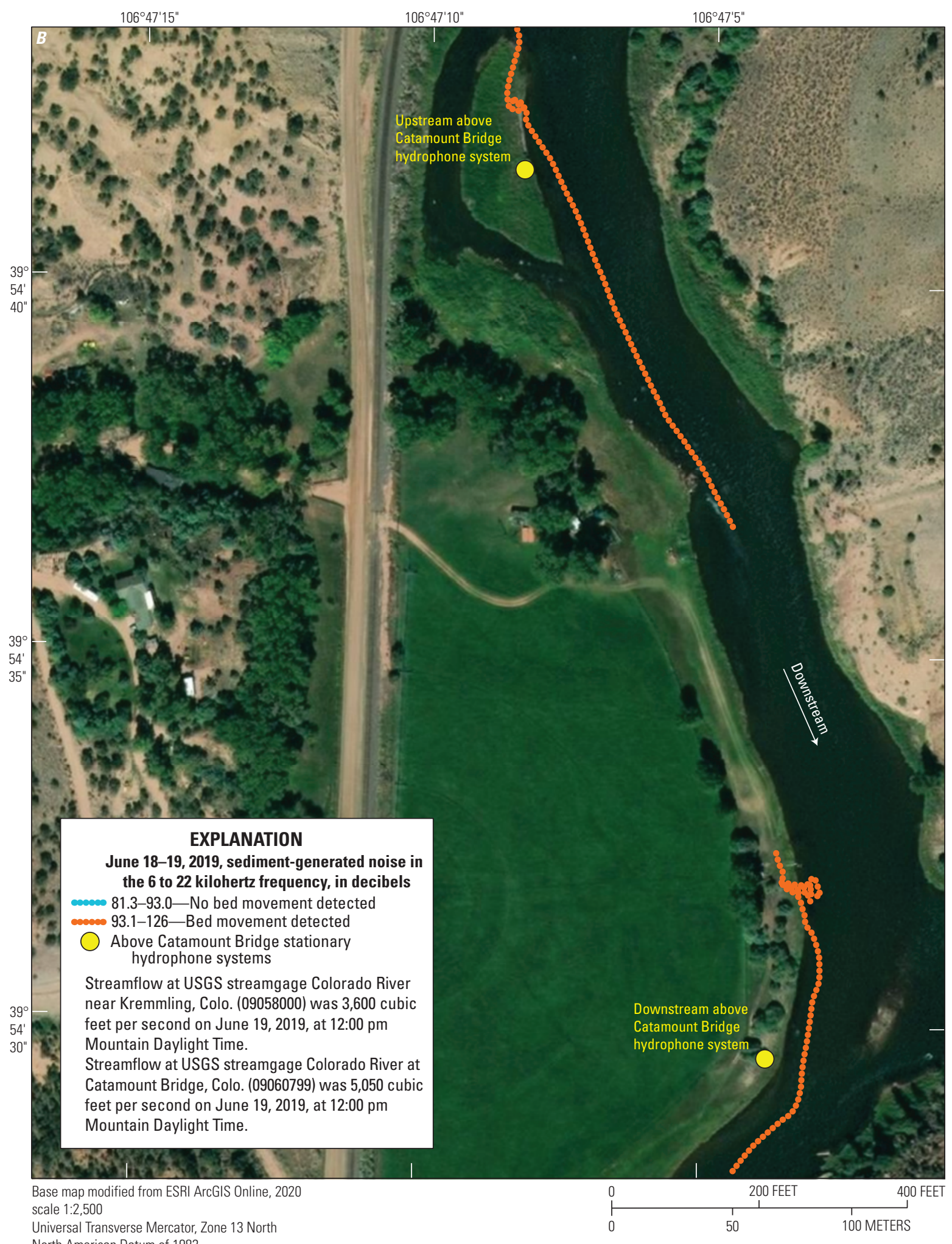

Figure 12. - Continued 


\section{Longitudinal Acoustic Doppler Current Profiler}

Three streamflow measurements were made to document the streamflow accumulation on the upper Colorado River during the June 6-8 longitudinal profile (table 7). Streamflow increased substantially during the June 6-8 longitudinal profile, primarily driven by tributary inflow but also by an increase in streamflow observed at the Kremmling streamgage. Channel width and cross-sectional area of the three measurements were similar, but the lower average cross-sectional velocity at the Radium site could be responsible for the higher streamflows needed to mobilize the streambed at the Radium site (table 4).

\section{Pebble Counts}

Streambed surface particles at the above Catamount Bridge stationary hydrophone monitoring reach locations were two-times coarser than those at the Radium stationary hydrophone system locations (table 8, fig. 1). The grain-size distributions at the upstream and downstream stationary hydrophones systems of individual sites were similar (figs. 16 and 17), indicating that differences in grain-size distribution were greatest between, rather than among, the two stationary hydrophone sites. Generally, streambed materials become finer downstream because of comminution (O'Connor and others, 2014) and selective movement (Ferguson and others, 1996), but at these sites, the opposite pattern was observed. Two notable differences may explain the presence of finer material at the Radium stationary hydrophone site. First, both pebble counts at Radium were collected in depositional zones on the margins of the channel, including a detached point bar and an eddy bar. During the pebble counts, sampling of coarser riffles was not possible because the stream was too deep to wade. In comparison, pebble counts at the above Catamount stationary hydrophone site were collected adjacent to riffles, where pebbles tend to be coarser. Secondly, both Radium stationary hydrophone monitoring reach locations are located approximately 3,000 ft downstream from a tributary (Sheephorn Creek; fig. 1), which may contribute finer material that is deposited locally. At both the above Catamount Bridge and Radium stationary hydrophone sites, the surface particles were sampled adjacent to stationary hydrophones and, therefore, represent the material locally available for movement. The particles sampled at the above Catamount Bridge stationary hydrophone site are likely more representative of larger framework gravels that compose riffles or coarse marginal deposits mobilized at higher streamflows, whereas the particles sampled at Radium likely are representative of smaller gravels that are transported at lower streamflows.

\section{Flushing Flows}

A variety of factors could affect the flushing flows from year to year, but these factors can only be determined if additional data are collected. Based on the data collected in 2019 presented in this report, bed movement occurred more frequently and at lower streamflows from State Bridge to Catamount Bridge compared to the part of the study area upstream from State Bridge (figs. 9 and 10; tables 4 and 6). As a result, the flushing flow was characterized in the study area using two definitions, the "upstream flushing flow" for locations upstream from State Bridge and the "downstream flushing flow" for locations downstream from State Bridge. The upstream (represented by the Radium stationary hydrophone site) and downstream (represented by the above Catamount Bridge stationary hydrophone site) flushing flows, as defined in table 4, were verified using the acoustic longitudinal hydrophone profile data at the stationary hydrophone systems (figs. 11 and 12). The upstream flushing flow was defined as $3,000 \mathrm{ft} 3 / \mathrm{s}$ at the Kremmling streamgage based on the downstream Radium stationary hydrophone underwater acoustic data $(2,950 \mathrm{ft} 3 / \mathrm{s}$ at the Kremmling streamgage) defined in table 4 . The upstream Radium stationary hydrophone underwater acoustic data were not used in this definition because the large eddy that existed near that hydrophone at high flows, but which was not present at low flows when the site was selected, caused the data collected at this location to be unrepresentative of riffles in the study area. The downstream flushing flow was defined as 2,400 ft3/s at the Kremmling streamgage or $3,100 \mathrm{ft}^{3} / \mathrm{s}$ at the Catamount streamgage based on the more conservative streamflow associated with the flushing flow defined using the downstream above Catamount Bridge stationary underwater acoustic data $\left(2,310 \mathrm{ft}^{3} / \mathrm{s}\right.$ at the Kremmling streamgage which was rounded to $2,400 \mathrm{ft}^{3} / \mathrm{s}$ and $3,040 \mathrm{ft}^{3} / \mathrm{s}$ at the Catamount streamgage which was rounded to $3,100 \mathrm{ft}^{3} / \mathrm{s}$ ) defined in table 4 . 


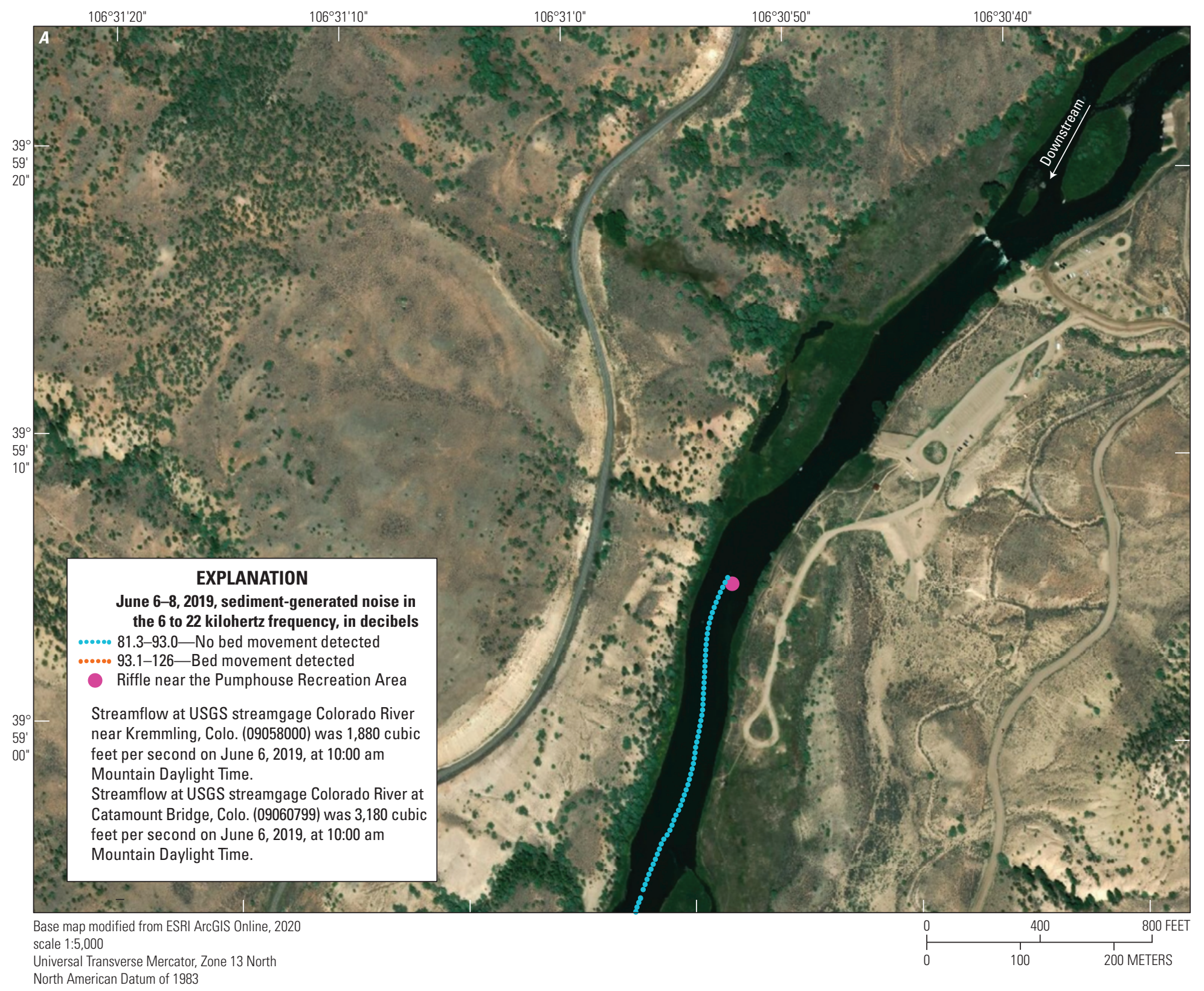

Figure 13. Maps showing where bed movement was detected (in orange) or was not detected (in blue) at the riffle near the Pumphouse Recreation Area during the $A$, June 6-8, 2019, and $B$, June 18-19, 2019, longitudinal profiles. The hydrophones were not deployed in the water until the most upstream data point. (Colo., Colorado; USGS, U.S. Geological Survey) 


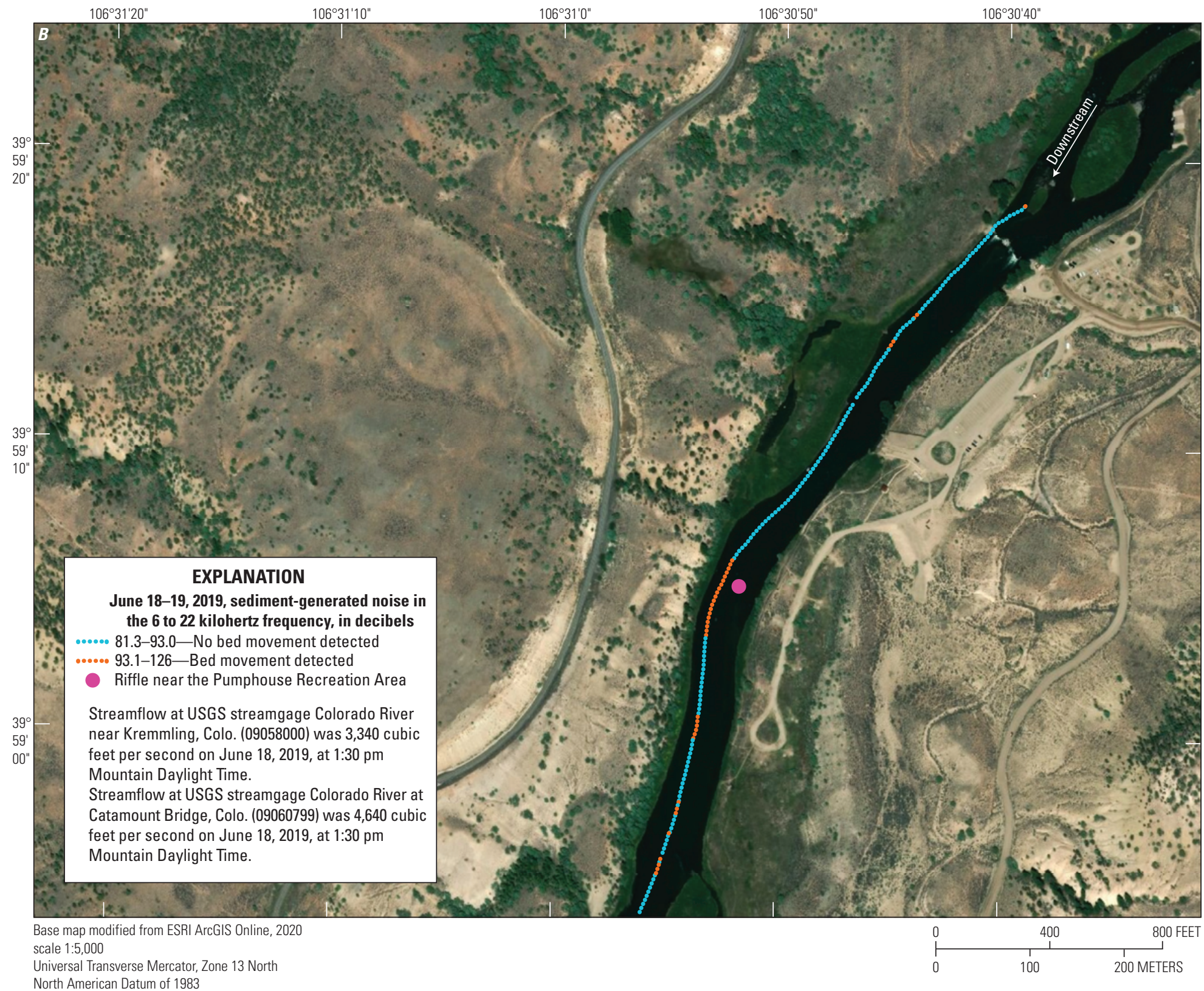

Figure 13. - Continued 


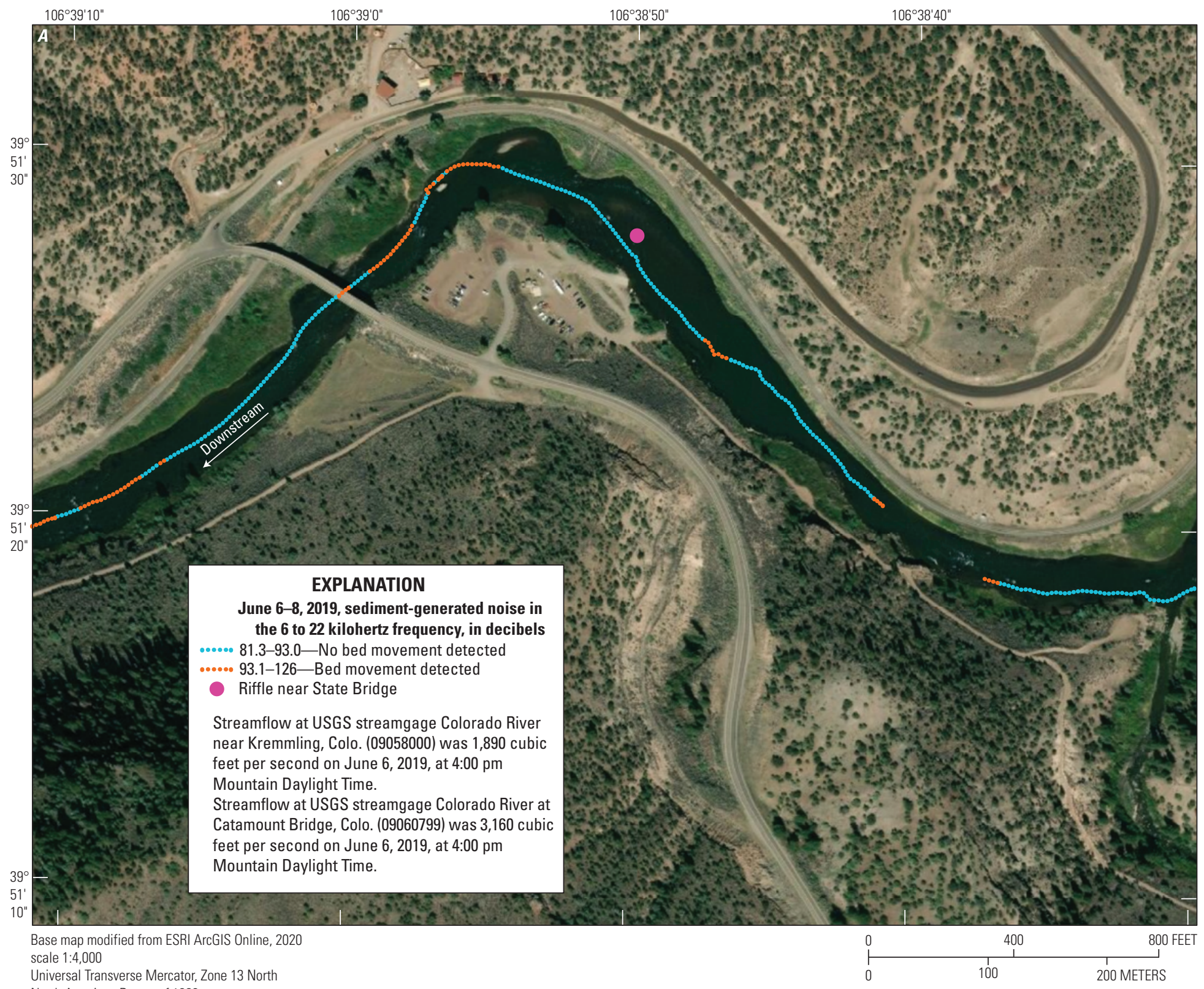

Figure 14. Maps showing where bed movement was detected (in orange) or was not detected (in blue) at the riffle near State Bridge during the $A$, June 6-8, 2019, and $B$, June 18-19, 2019, longitudinal profiles. (Colo., Colorado; USGS, U.S. Geological Survey) 


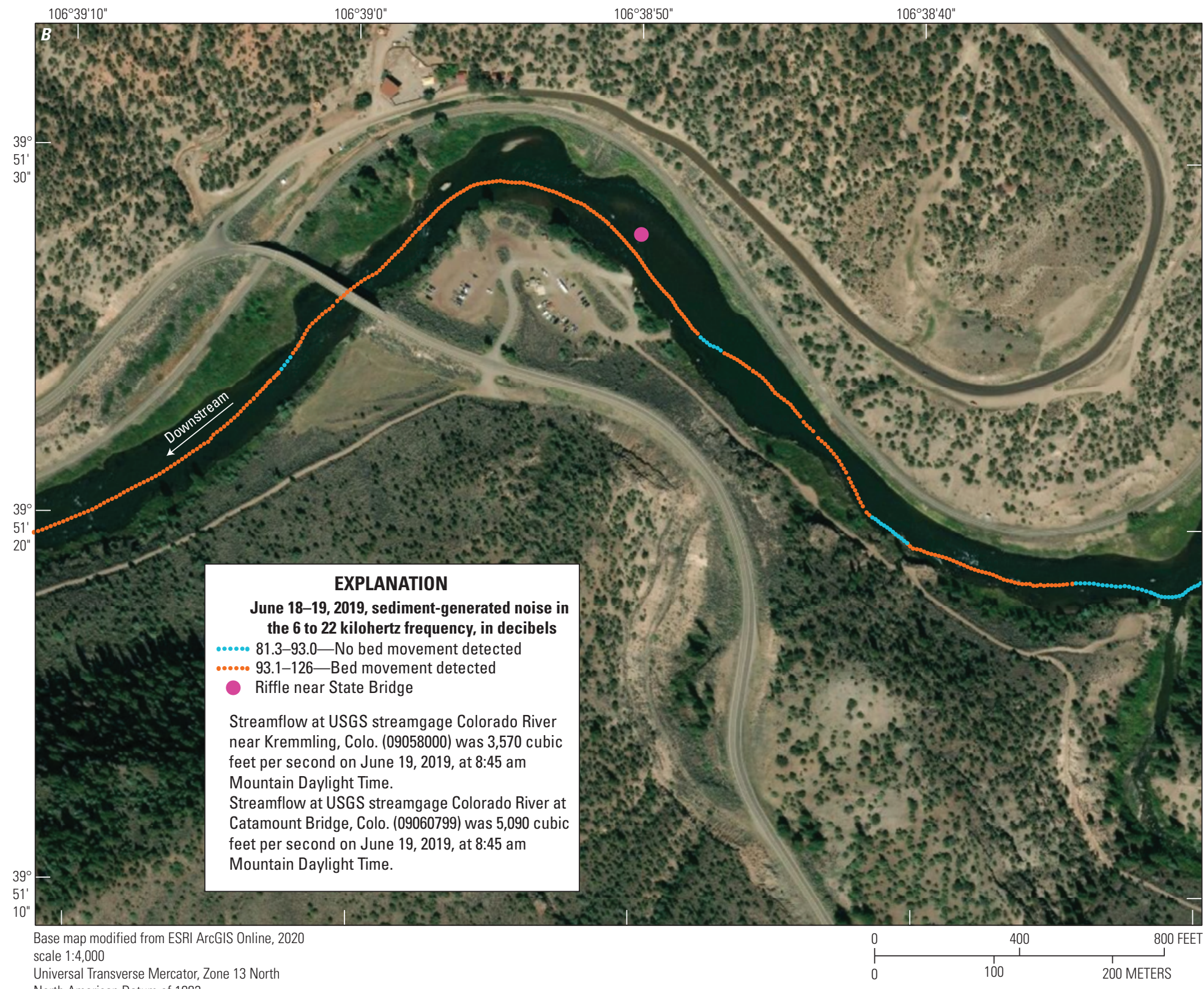

Figure 14. - Continued 


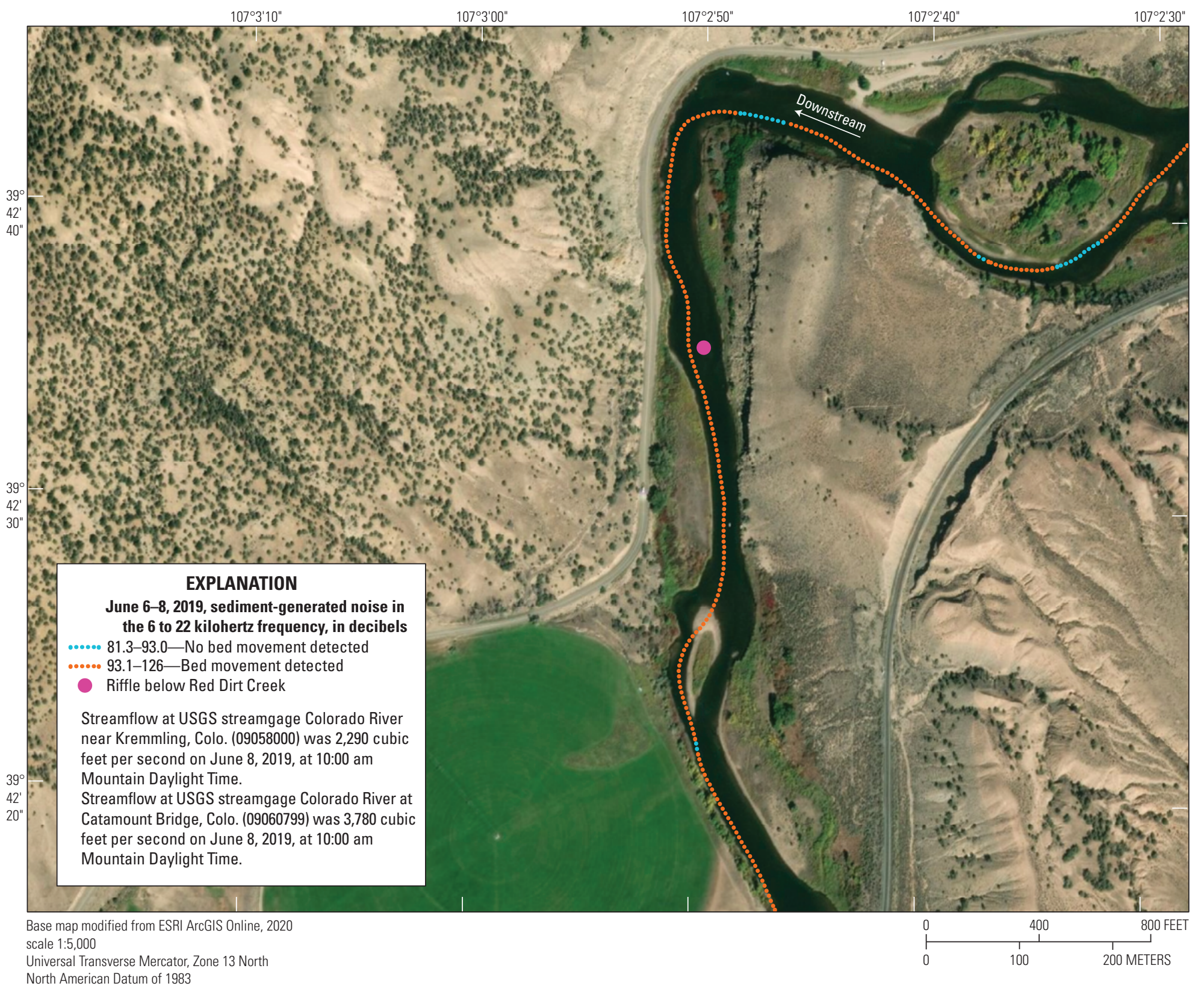

Figure 15. Map showing where bed movement was detected (in orange) or was not detected (in blue) at the riffle below Red Dirt Creek during the June 6-8, 2019, longitudinal profile. (Colo., Colorado; USGS. U.S. Geological Survey) 


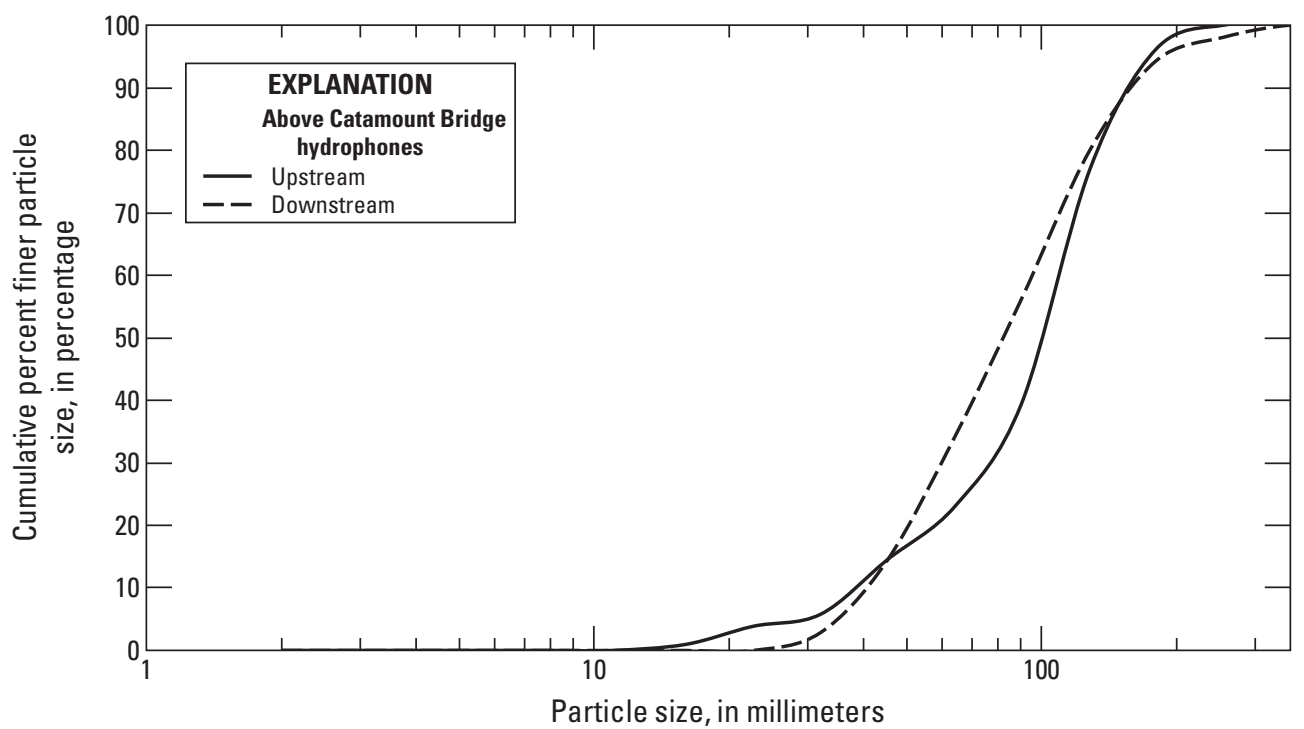

Figure 16. Graph showing grain-size distributions of Wolman pebble counts (1954) presented as cumulative percent finer particle size at the upstream and downstream above Catamount Bridge stationary hydrophone monitoring reach locations.

Table 7. Streamflow measurements made with an acoustic Doppler current profiler during the June $6-8,2019$, longitudinal profile to summarize the streamflow accumulation in the upper Colorado River Basin.

[Cow Camp is a campsite along the Colorado River where the longitudinal profile data collection ended on June 6, 2019, and where the longitudinal profile data collection began on June 7, 2019. ft, foot; ft/s, feet per second; ft2, square foot; $\mathrm{ft} 3 / \mathrm{s}$, cubic feet per second; HH, two-digit hour; Mm, two-digit minute]

\begin{tabular}{lcccccccc}
\hline $\begin{array}{c}\text { Site } \\
\text { location }\end{array}$ & $\begin{array}{c}\text { Latitude } \\
\text { (decimal } \\
\text { degrees) }\end{array}$ & $\begin{array}{c}\text { Longitude } \\
\text { (decimal } \\
\text { degrees) }\end{array}$ & Date & $\begin{array}{c}\text { Start time } \\
\text { (HH:Mm) }\end{array}$ & $\begin{array}{c}\text { Streamflow } \\
\text { (ft3/s) }\end{array}$ & $\begin{array}{c}\text { Channel } \\
\text { width (ft) }\end{array}$ & $\begin{array}{c}\text { Cross-sectional } \\
\text { area (ft2) }\end{array}$ & $\begin{array}{c}\text { Average } \\
\text { cross-sectional } \\
\text { velocity (ft/s) }\end{array}$ \\
\hline Radium & 39.9517 & -106.5578 & $06 / 06 / 2019$ & $11: 47$ & 2,340 & 161 & 593 & 3.95 \\
Cow Camp & 39.9068 & -106.7721 & $06 / 06 / 2019$ & $19: 10$ & 2,930 & 151 & 606 & 4.83 \\
Cow Camp & 39.9068 & -106.7720 & $06 / 07 / 2019$ & $09: 51$ & 3,380 & 158 & 653 & 5.17 \\
\hline
\end{tabular}

Table 8. Grain sizes of the 16th (D16), 50th (D50, median), and 84th (D84) percentiles from Wolman pebble counts (1954) at the four stationary hydrophone monitoring reach locations.

$[\mathrm{mm}$, millimeter]

\begin{tabular}{lcccc}
\hline $\begin{array}{c}\text { Grain-size } \\
\text { percentile }\end{array}$ & $\begin{array}{c}\text { Upstream Radium } \\
\text { stationary hydrophone }\end{array}$ & $\begin{array}{c}\text { Downstream Radium } \\
\text { stationary hydrophone }\end{array}$ & $\begin{array}{c}\text { Upstream above Catamount } \\
\text { Bridge stationary hydrophone }\end{array}$ & $\begin{array}{c}\text { Downstream above Catamount } \\
\text { Bridge stationary hydrophone }\end{array}$ \\
\hline $\mathrm{D}_{16}(\mathrm{~mm})$ & 17 & 12 & 48 & 46 \\
$\mathrm{D}_{50}(\mathrm{~mm})$ & 33 & 35 & 99 & 82 \\
$\mathrm{D}_{84}(\mathrm{~mm})$ & 52 & 59 & 145 & 141 \\
\hline
\end{tabular}




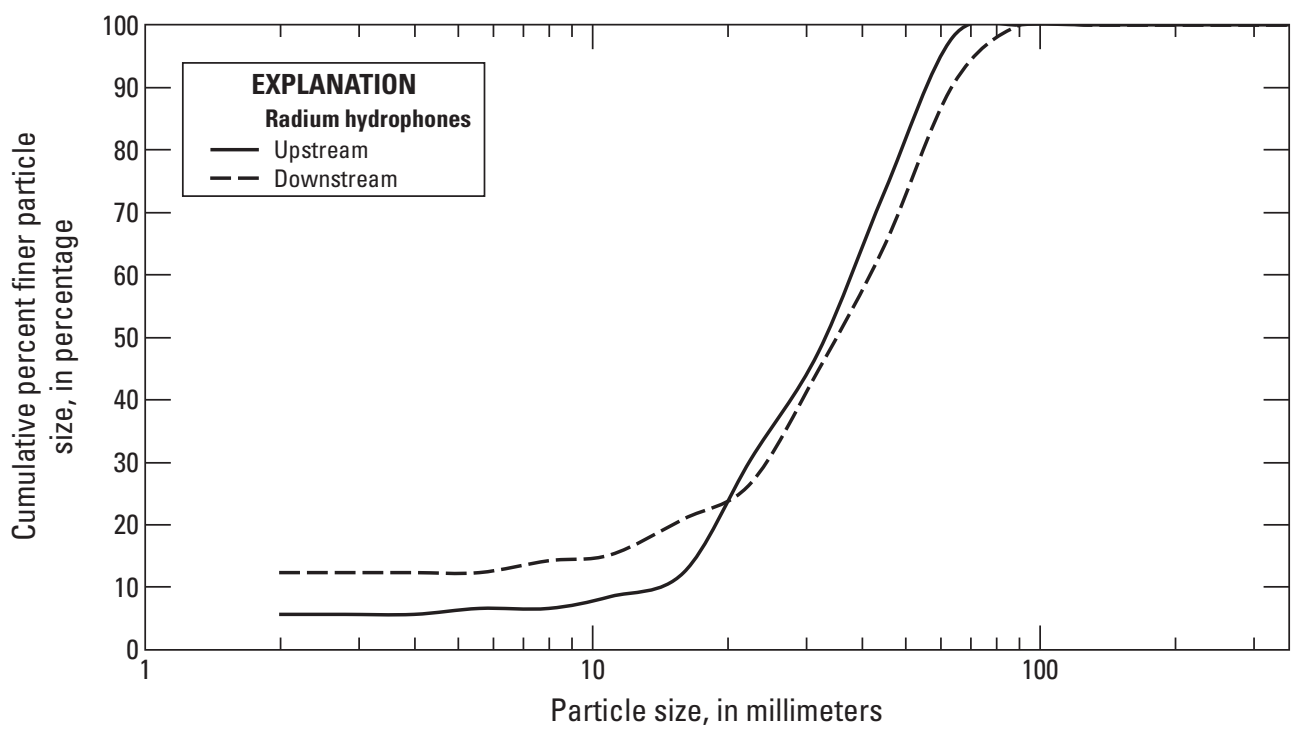

Figure 17. Graph showing grain-size distributions from Wolman pebble counts (1954) presented as cumulative percent finer particle size at the upstream and downstream Radium stationary hydrophone monitoring reach locations.

\section{Flood-Frequency Analysis}

Table 9 presents the estimated AEPDs for the historical record and for the 45 water years at the Kremmling streamgage based on future-flow conditions in the basin. Between 2007 and 2019, most of the annual-peak streamflows are greater than the post-dam era (that is, 1962-2019 after the Colorado-Big Thompson Project) average annual-peak streamflow of $4,060 \mathrm{ft} 3 / \mathrm{s}$ (USGS, 2020). As a result, the time periods that included data through water year 2019 had
AEPDs that were larger than the AEPDs for the time periods through water year 2006 for the same AEP. Time periods in table 9 are ordered by magnitude of the AEPD, and because peak streamflows have been larger in the last 20 years, time periods that include 2007-2019 are found on the right-hand side of the table 9 .

The upstream flushing flow, detected at the downstream Radium stationary hydrophone system, of approximately $3,000 \mathrm{ft}^{3} / \mathrm{s}$ at the Kremmling streamgage $(2,950 \mathrm{ft} 3 / \mathrm{s}$; table 4$)$ has an AEP near 0.50 (2-year return period) depending on

Table 9. Summary of the flood-frequency analyses for seven periods of record for the Colorado River near Kremmling, Colorado streamgage (U.S. Geological Survey streamgage 09058000).

$[\mathrm{ft} 3 / \mathrm{s}$, cubic feet per second]

\begin{tabular}{|c|c|c|c|c|c|c|c|c|c|}
\hline \multicolumn{2}{|c|}{$\begin{array}{c}\text { Time period } \\
\text { (water years'): }\end{array}$} & Future2 & 1985-2006 & 1982-2006 & 1983-2006 & 1985-2019 & 1990-2019 & 1982-2019 & 1983-2019 \\
\hline \multicolumn{2}{|c|}{ Record length (years): } & 45 & 22 & 25 & 24 & 35 & 30 & 38 & 37 \\
\hline 0.9 & 1.11 & 1,110 & 1,240 & 1,230 & 1,230 & 1,380 & 1,360 & 1,390 & 1,400 \\
\hline 0.67 & 1.50 & 1,940 & 2,070 & 2,190 & 2,220 & 2,470 & 2,510 & 2,540 & 2,580 \\
\hline 0.5 & 2.00 & 2,600 & 2,700 & 2,960 & 3,020 & 3,280 & 3,390 & 3,4409 & 3,500 \\
\hline 0.43 & 2.33 & 2,950 & 3,010 & 3,360 & 3,440 & 3,690 & 3,830 & 3,890 & 3,960 \\
\hline 0.2 & 5.00 & 4,780 & 4,540 & 5,440 & 5,590 & 5,630 & 5,940 & 6,160 & 6,280 \\
\hline
\end{tabular}

1Water year is the 12-month period from October 1 of one year through September 30 of the following year and is designated by the calendar year in which it ends.

${ }^{2}$ Future results provided by Denver Water Platte and Colorado Simulation Model. 
the period of historical record and near 0.43 (2.33-year return period) for the future period (table 9). The downstream flushing flow, detected at the downstream above Catamount Bridge stationary hydrophone system, of approximately $2,400 \mathrm{ft} 3 / \mathrm{s}$ at the Kremmling streamgage $(2,310 \mathrm{ft} 3 / \mathrm{s}$; table 4) has an AEP near 0.67 (1.5-year return period) depending on the period of historical record and near 0.67 (1.5-year return period) for the future period (table 9). The average streamflow $\left(2,100 \mathrm{ft}^{3} / \mathrm{s}\right.$; table 5) detected at the Kremmling streamgage during the June 6-8 longitudinal profile has an AEP near 0.67 (1.5-year return period) depending on the period of historical record and near 0.67 (1.5-year return period) for the future period (table 9). The average streamflow of 3,480 ft3 $3 / \mathrm{s}$ (table 5) detected at the Kremmling streamgage during the June 18-19 longitudinal profile has an AEP near 0.43 (2.33-year return period) depending on the period of historical record and near 0.43 (2.33-year return period) for the future period (table 9).

Figures 18 and 19 provide historical and future context on the temporal frequency of the upstream and downstream flushing flow. Figure $18 \mathrm{~A}$ summarizes the number of consecutive days where the daily average streamflow at the Kremmling streamgage exceeded the upstream flushing flow in the past 30 water years (1990-2019), which results in an average of 16.1 days. Figure $18 B$ summarizes the number of consecutive days where the daily average streamflow at the Kremmling streamgage has exceeded the upstream flushing flow based on 45 years of modeling results of future conditions from Denver Water's Platte and Colorado Simulation Model, which results in an average of 9.1 days (Alex Bowen, Denver Water, written commun., January 23, 2020).

Figure $19 \mathrm{~A}$ summarizes the number of consecutive days where the daily average streamflow at the Kremmling streamgage exceeded the downstream flushing flow in the past 30 water years (1990-2019), which results in an average of 22.3 days. Figure $19 B$ summarizes the number of consecutive days where the daily average streamflow at the Kremmling streamgage has exceeded the downstream flushing flow based on 45 years of modeling results of future conditions from Denver Water's Platte and Colorado Simulation Model, which results in an average of 13.1 days (Alex Bowen, Denver Water, written commun., January 14, 2020).

Not surprisingly, daily average streamflow at the Kremmling streamgage is highly variable yet consistently cyclical, which results in the average being less than the standard deviation for both the historical and future periods (figs. 18 and 19). The streamflow of the upper Colorado River is highly managed, so there are dry periods when a flushing flow will not occur at the Kremmling streamgage; however, there will be wetter periods when flushing flows will happen many days in a year (figs. 18 and 19). Figures 18 and 19 also demonstrate that historically, when the flushing flow is exceeded, it generally occurs for several consecutive days in that water year.

\section{Information Needs}

The results presented in this report are based on data collected during 2019. From year to year, flushing flows could be affected by a variety of factors that can only be determined if additional data are collected. First, additional monitoring in the study area upstream from State Bridge because the data in this report suggest this reach requires larger streamflow to mobilize the gravel or finer-sized sediment in the streambed, which defines the flushing flow for this study. If fish spawning data were available at specific spawning areas, those locations could be monitored with stationary hydrophones, and the resulting data used as a correlation between spawning production and bed movement, which would be a critical tool to help define a flushing flow for these specific areas. Alternatively, a reach-scale approach from Pumphouse Recreation Area to State Bridge using additional longitudinal hydrophone profiles at $500 \mathrm{ft} 3 / \mathrm{s}$ intervals starting at 1,500 ft3/s, which is near the peak flow in drought years (USGS, 2020), would provide spatial definition of the bed movement in riffles in the study area.

Second, pebble count, hydraulic, and topographic data were collected at the above Catamount Bridge stationary hydrophones in 2019. These data could be used to build a multidimensional sediment transport model that could be calibrated to the stationary underwater acoustic data collected using hydrophones in the same reach. This local-scale model could then be expanded to larger reaches in the study area and used to inform decision makers on the flushing-flow thresholds on a broader scale.

Third, additional underwater acoustic data collection at the Radium and above Catamount Bridge stationary hydrophone system monitoring reach locations would inform decision makers on the annual variability of the flushing flow and how dependent it may be on the previous year's hydrology, the size and shape of the current year's hydrograph, or the effect of the relative native tributary streams in the study area. Underwater acoustic data collected with hydrophones could be used in conjunction with bedload measurements to estimate the size and distribution of the bed movement.

Fourth, a relatively inexpensive way to measure whether gravel or finer-sized sediment in the streambed has been mobilized by a hydrologic event, which defines the flushing flow, would be to use the freeze-core method in the spring prior to peak runoff and again in late summer after peak runoff. In the freeze-core method, a hollow tube is inserted vertically into the streambed and filled with dry ice or liquid nitrogen, which causes the adjacent streambed material to freeze in place, then the core is removed, and a grain-size analysis can be performed. An alternative method to the freeze-core method is using tracer pebbles or radio-frequency identification on pebbles placed in the streambed prior to peak streamflow followed by documenting their displacement after peak streamflow. 

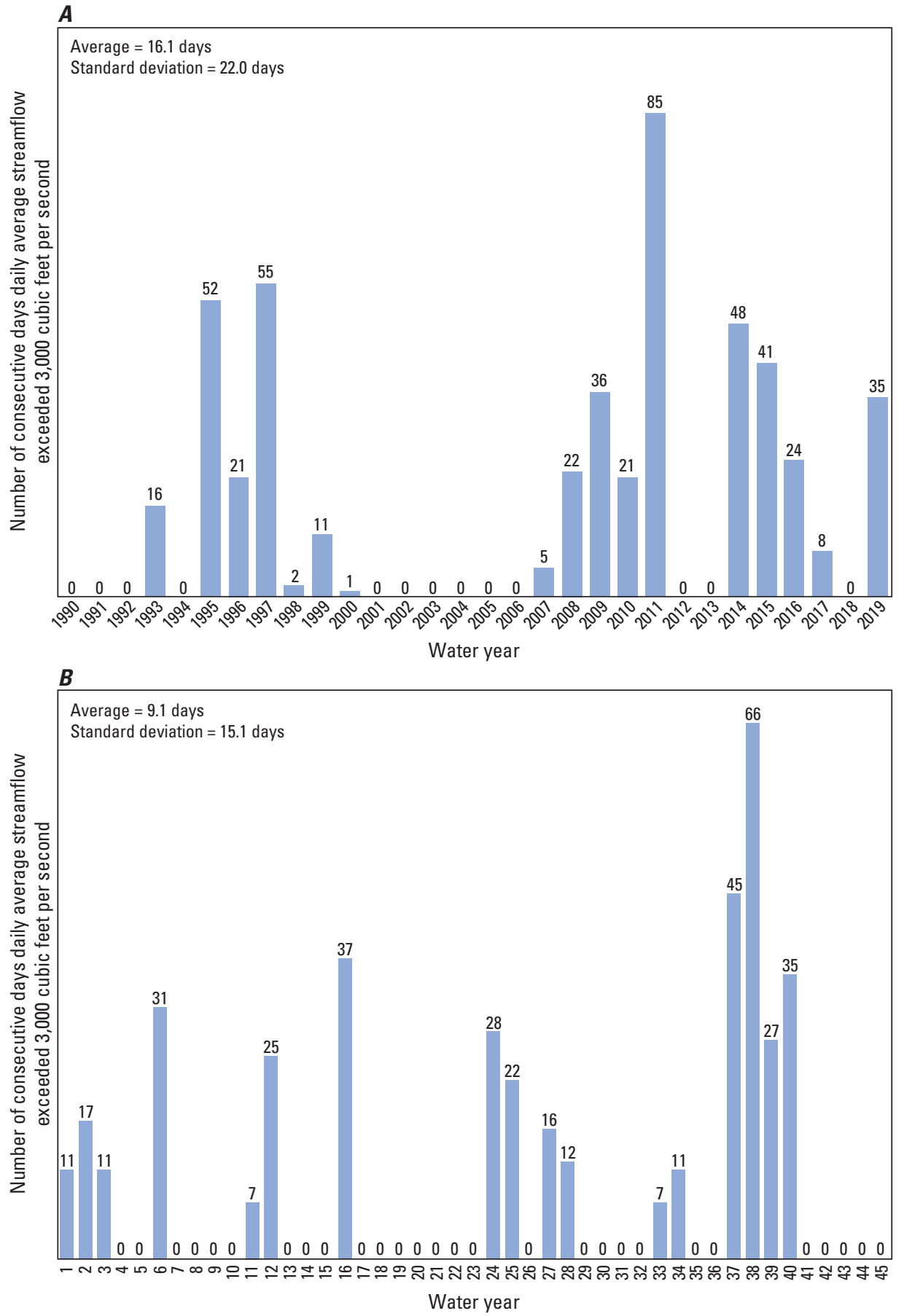

Figure 18. Graphs showing the number of consecutive days based on $A$, historical data and $B$, future conditions, where the daily average streamflow exceeded 3,000 cubic feet per second at the U.S. Geological Survey (USGS) streamgage Colorado River near Kremmling, Colorado (USGS streamgage number 09058000). 

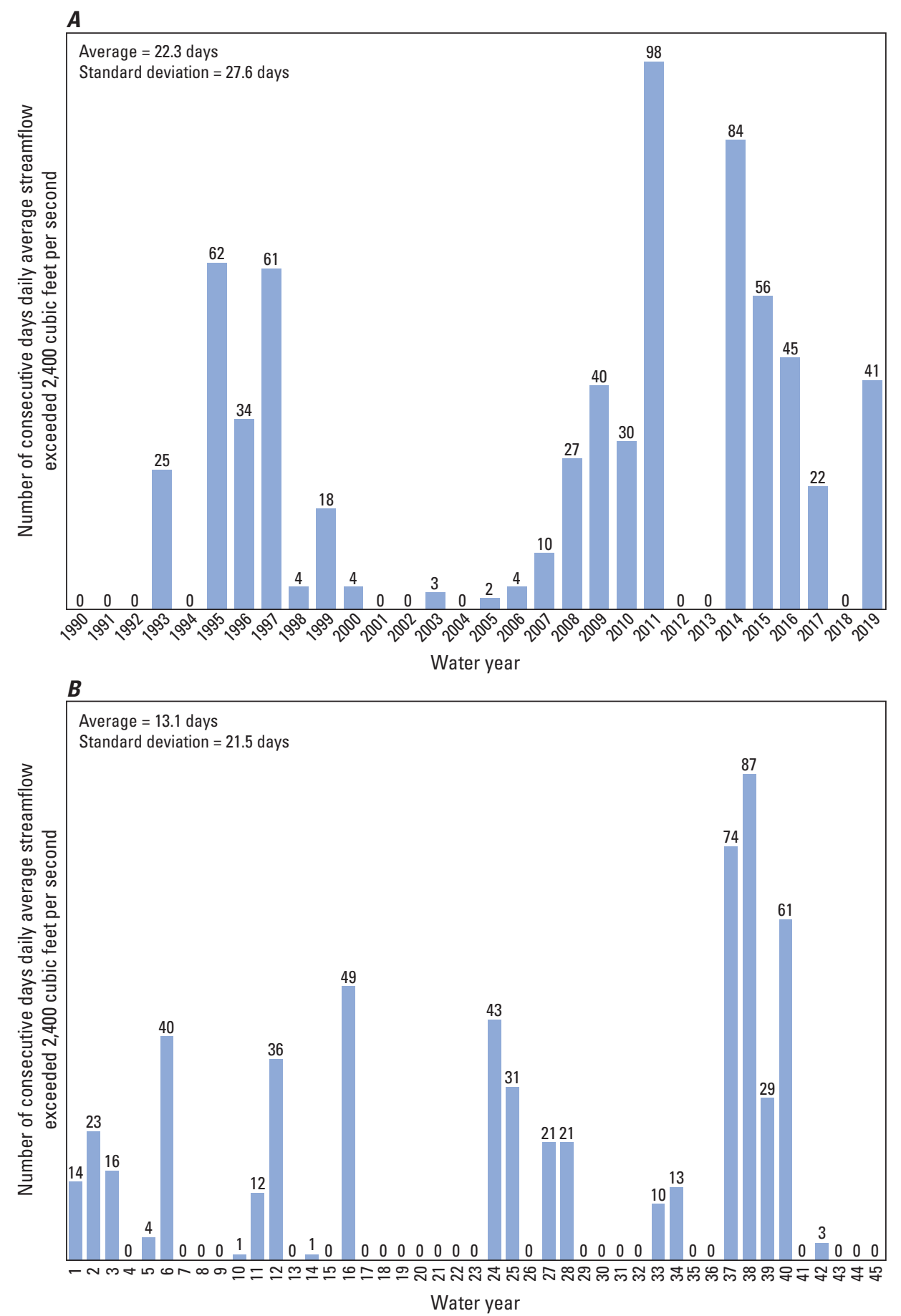

Figure 19. Graphs showing the number of consecutive days based on $A$, historical data and $B$, future conditions, where the daily average streamflow exceeded 2,400 cubic feet per second at the U.S. Geological Survey (USGS) streamgage Colorado River near Kremmling, Colorado (USGS streamgage number 09058000). 


\section{Summary}

In 2019, the U.S. Geological Survey (USGS), in cooperation with the with Upper Colorado River Wild and Scenic Stakeholder Group, studied the magnitude and recurrence interval of streamflow (discharge) needed to initiate bed movement of gravel-sized and finer sediment in a segment of the Colorado River to better understand sediment movement and its relation to flow regimes of the river. Flushing flows move gravel-sized or finer sediment in riffles to maintain spawning habitat for fish and maintain substrate and interstitial spaces for benthic macroinvertebrates. The Upper Colorado River Wild and Scenic Stakeholder Group Management Plan was implemented as a Wild and Scenic Rivers management alternative by the Upper Colorado River Wild and Scenic Stakeholder Group, which represents a broad range of interests, including east- and west-slope water users, local governments, State agencies, and conservation, environmental, fishing, and float-boating interest groups. The study area extended from the confluence of the Blue and Colorado Rivers near Kremmling, Colo., downstream to the confluence of the Eagle and Colorado Rivers near Dotsero, Colo. Bed movement occurred more frequently and at lower streamflows from State Bridge to Catamount Bridge compared to the study area upstream from State Bridge.

Acoustic data from stationary hydrophones that were continuously deployed in the spring and summer 2019 and longitudinal hydrophone acoustic profiles that were manually collected in summer 2019 were used to identify the streamflow needed for incipient gravel-bed movement and establish flushing flows as defined for this study. Based on the data presented in this report, bed movement occurred more frequently and at lower streamflows from State Bridge to Catamount Bridge compared to the part of the study area upstream from State Bridge. As a result, the flushing flow was characterized in the study area using two definitions, the "upstream flushing flow" for locations above State Bridge and the "downstream flushing flow" for locations below State Bridge. The upstream and downstream flushing flows were verified using the acoustic longitudinal hydrophone profile data at the stationary hydrophone systems. The upstream flushing flow was defined as 3,000 cubic feet per second ( $\mathrm{ft} 3 / \mathrm{s})$ at the USGS streamgage Colorado River near Kremmling, Colo. (USGS streamgage number 09058000) based on the downstream Radium stationary underwater acoustic data $\left(2,950 \mathrm{ft}^{3} / \mathrm{s}\right.$ at the Kremmling streamgage). The downstream flushing flow was defined as $2,400 \mathrm{ft} 3 / \mathrm{s}$ at the Kremmling streamgage or $3,100 \mathrm{ft} 3 / \mathrm{s}$ at the USGS streamgage Colorado River at Catamount Bridge, Colo. (USGS streamgage number 09060799) based on the more conservative streamflow associated with the flushing flow defined using the downstream above Catamount Bridge stationary underwater acoustic data $\left(2,310 \mathrm{ft}^{3} / \mathrm{s}\right.$ at the Kremmling streamgage which was rounded to $2,400 \mathrm{ft} 3 / \mathrm{s}$ and $3,040 \mathrm{ft} 3 / \mathrm{s}$ at the Catamount streamgage which was rounded to $3,100 \mathrm{ft} 3 / \mathrm{s}$ ).
The annual series of peak-streamflow data at the Kremmling streamgage were used to estimate annual exceedance probability (AEP) streamflows to compare to the flushing flow. Results from the Denver Water Platte and Colorado Simulation Model were used to generate daily peak-streamflows for a future conditions scenario provided for this report. The upstream flushing flow of approximately $3,000 \mathrm{ft} 3 / \mathrm{s}$ at the Kremmling streamgage has an AEP near 0.50 (2-year return period) depending on the period of historical record and an AEP near 0.43 (2.33-year return period) for the future period. The downstream flushing flow of approximately $2,400 \mathrm{ft}^{3} / \mathrm{s}$ at the Kremmling streamgage has an AEP near 0.67 (1.5-year return period) depending on the period of historical record and an AEP near 0.67 (1.5-year return period) for the future period.

Additional monitoring would be beneficial in the study area upstream from State Bridge because the data in this report indicate this reach requires larger streamflow to mobilize the gravel or finer-sized sediment in the streambed, which defines the flushing flow for this study. If fish spawning data were available at specific spawning areas, those locations could be monitored with stationary hydrophones and the resulting data used as a correlation between spawning production and bed movement, which would be a critical tool to help define a flushing flow for these specific areas. Alternatively, a reach-scale approach from Pumphouse Recreation Area to State Bridge using additional longitudinal hydrophone profiles at $500 \mathrm{ft}^{3} / \mathrm{s}$ intervals starting at $1,500 \mathrm{ft} 3 / \mathrm{s}$, which is near the peak flow in drought years, would provide spatial definition of the bed movement in riffles in the study area.

\section{References Cited}

\author{
Adafruit Industries, 2020, Ultimate GPS Module, 66 \\ channel w/10 Hz updates-MTK3339 chipset: Adafruit \\ Industries web page, accessed April 20, 2020, at \\ https://www.adafruit.com/product/790.
}

Aquarian Audio, 2013, Aquarian Audio Products H1a Hydrophone User's Guide: Anacortes, Wash., Aquarian Audio Products, 2 p., accessed December 16, 2019, at https://www.aquarianaudio.com/AqAudDocs/H1a manual.pdf.

American Society of Civil Engineers, 2020, Moffat Tunnel: American Society of Civil Engineers web page, accessed June 18, 2020, at https://www.asce.org/project/ moffat-tunnel/. 
Barton, J.S., Slingerland, R.L., Pittman, S., and Gabrielson, T.B., 2010, Monitoring coarse bedload transport with passive acoustic instrumentation-A field study, in Gray, J.R., Laronne, J.B., and Marr, J.D.G., 2010, Bedload-surrogate monitoring technologies: U.S. Geological Survey Scientific Investigations Report 2010-5091, p. 38-51, accessed January 2, 2020, at https://pubs.usgs.gov/sir/2010/5091/papers/Barton.pdf.

Bedeus, K., and Iviscics, L., 1964, Observation of the noise of bedload: Proceedings of the International Association of Hydrological Sciences, v. 65, p. 384-390.

Beeby, J., and Bledsoe, B., 2015, Bed material and flushing analysis for the Colorado River in Eagle County: Gypsum, Colo., Eagle River Watershed Council, prepared by Colorado State University, 18 p.

Beeby, J., Bledsoe, B., and Hardie, K., 2014, Colorado River in Eagle County inventory and assessment: Gypsum, Colo., Eagle River Watershed Council, prepared by Colorado State University, $273 \mathrm{p}$.

Bunte, K., and Abt, S.R., 2001, Sampling surface and subsurface particle-size distributions in wadable graveland cobble-bed streams for analyses in sediment transport, hydraulics, and streambed monitoring: U.S. Department of Agriculture, Forest Service, Rocky Mountain Research Station, General Technical Report RMRS-GTR-74, 428 p.

Bureau of Reclamation, 2020, Great Plains Region-Eastern Colorado Area Office: Bureau of Reclamation web page, accessed February 7, 2020, at https://www.usbr.gov/gp/ ecao/index.html.

Cohn, T.A., England, J.F., Berenbrock, C.E., Mason, R.R., Stedinger, J.R., and Lamontagne, J.R., 2013, A generalized Grubbs-Beck test statistic for detecting multiple potentially influential low outliers in flood series: Water Resources Research, v. 49, no. 8, p. 5047-5058. [Also available at https://doi.org/10.1002/wrcr.20392.]

Colorado Division of Water Resources, 2019, Colorado's Surface Water Conditions: Colorado Division of Water Resources database, accessed December 9, 2019, at https://dwr.state.co.us/surfacewater/.

Denver Water, 2020, Collection system: Denver Water web page, accessed February 7, 2020, at https://www.denverwater.org/your-water/water-supply-andplanning/collection-system.

Eash, D.A., Barnes, K.K., and Veilleux, A.G., 2013, Methods for estimating annual exceedance-probability discharges for streams in Iowa, based on data through water year 2010: U.S. Geological Survey Scientific Investigations Report 2013-5086, 63 p. with appendix, accessed December 18, 2019, at https://doi.org/10.3133/sir20135086.
England, J.F., Jr., Cohn, T.A., Faber, B.A., Stedinger, J.R., Thomas, W.O., Jr., Veilleux, A.G., Kiang, J.E., and Mason, R.R., Jr., 2019, Guidelines for determining flood flow frequency-Bulletin 17C (ver. 1.1, May 2019): U.S. Geological Survey Techniques and Methods, book 4, chap. B5, 148 p., accessed December 18, 2019, at https://doi.org/10.3133/tm4B5.

Ferguson, R., Hoey, T., Wathen, S., and Werritty, A., 1996, Field evidence for rapid downstream fining of river gravels through selective transport: Geology, v. 24, no. 2, p. 179-182. [Also available at https://doi.org/10.1130/00917613(1996)024<0179:FEFRDF>2.3.CO;2.]

Gotvald, A.J., Barth, N.A., Veilleux, A.G., and Parrett, C., 2012, Methods for determining magnitude and frequency of floods in California, based on data through water year 2006: U.S. Geological Survey Scientific Investigations Report 2012-5113, 38 p., 1 pl., accessed December 18, 2019, at https://doi.org/10.3133/sir20125113.

Grand County, Colorado, 2010, Stream Management Plan, Phase 3, Grand County Colorado-Draft report: Hot Sulphur Springs, Colo., Grand County, Colorado, prepared by Tetra Tech, HabiTech, Inc., and Walsh Aquatic, Inc., 37 p.

Interagency Advisory Committee on Water Data, 1982, Guidelines for determining flood flow frequency-Bulletin 17B of the Hydrology Subcommittee: Reston, Va., U.S. Geological Survey, Office of Water Data Coordination, 28 p. and appendixes, accessed December 18, 2019, at https://water.usgs.gov/osw/bulletin17b/dl_flow.pdf.

Kohn, M.S., and Hempel, L.A., 2020, Acoustic, spatial, and sediment size data collected on the upper Colorado River to estimate the flushing flows, Colorado, 2019: U.S. Geological Survey Data Release, https://doi.org/10.5066/P9J5L78O.

Kohn, M.S., Stevens, M.R., Harden, T.M., Godaire, J.E., Klinger, R.E., and Mommandi, A., 2016, Paleoflood investigations to improve peak-streamflow regional-regression equations for natural streamflow in eastern Colorado, 2015: U.S. Geological Survey Scientific Investigations Report 2016-5099, 58 p., accessed January 3, 2020, at https://doi.org/10.3133/sir20165099.

Kondolf, G.M., and Wilcock, P.R., 1996, The flushing flow problem-Defining and evaluating objectives: Water Resources Research, v. 32, no. 8, p. 2589-2599. [Also available at https://doi.org/10.1029/96WR00898.]

Kramer, H., 1935, Sand mixtures and sand movement in fluvial model: Transactions of the American Society of Civil Engineers, v. 100, no. 1, p. 798-838. 
Ligon, F.K., Dietrich, W.E., and Trush, W.J., 1995, Downstream ecological effects of dams: Bioscience, v. 45, no. 3, p. 183-192. [Also available at https://doi.org/10.2307/ 1312557.]

Marineau, M.D., Minear, J.T., and Wright, S.A., 2015, Using hydrophones as a surrogate monitoring technique to detect temporal and spatial variability in bedload movement, in The 3rd Joint Federal Interagency Conference (10th Federal Interagency Sedimentation Conference and 5th Federal Interagency Hydrologic Modeling Conference), Reno, Nev., April 19-23, 2015, Proceedings: Advisory Committee on Water Information, p. 617-628.

Marineau, M.D., Wright, S.A., and Gaeuman, D., 2016, Calibration of sediment-generated noise measured using hydrophones to bedload movement in the Trinity River, California, USA, in Constantinescu, G., Garcia, M., and Hanes, D., eds., River Flow 2016-Proceedings of the International Conference on Fluvial Hydraulics, St. Louis, Mo., July 11-14, 2016: London, CRC Press, Paper No 222, p. 1519-1526.

Marineau, M.D., Wright, S.A., and Gaeuman, D., 2017, Estimating bedload movement along the gravel-bedded Trinity River using in-situ and boat-mounted hydrophones, in The ASCE Hydraulic Measurements and Experimental Methods (HMEM) Conference, Durham, N.H., July 10-12, 2017, Proceedings: Reston, Va., American Society of Engineers, 6 p., accessed May 27, 2020, at https://www.eventscribe.com/2017/HMEM/assets/handouts/ 455641.pdf.

Miller, W.J., and Swaim, K.M., 2011, Final instream flow report for the Colorado River from Kremmling, Colorado downstream to Dotsero, Colorado: Fort Collins, Colo., Larimer County, Colorado, prepared by Miller Ecological Consultants, Inc., 288 p.

Mueller, D.S., 2016, QRev—Software for computation and quality assurance of acoustic Doppler current profiler moving-boat streamflow measurements-Technical manual for version 2.8: U.S. Geological Survey Open-File Report 2016-1068, 79 p., accessed January 7, 2020, at https://doi.org/10.3133/ofr20161068.

Mueller, D.S., Wagner, C.R., Rehmel, M.S., Oberg, K.A,, and Rainville, F., 2013, Measuring discharge with acoustic Doppler current profilers from a moving boat (ver. 2.0, December 2013): U.S. Geological Survey Techniques and Methods, book 3, chap. A22, 95 p., accessed January 7, 2020, at https://doi.org/10.3133/tm3A2.

Northern Colorado Water Conservancy District, 2020, Windy Gap Project: Northern Colorado Water Conservancy District web page, accessed June 18, 2020, at https://www.northernwater.org/WaterProjects/ WindyGapProject.aspx.
O’Connor, J.E., Mangano, J.F., Anderson, S.W., Wallick, J.R., Jones, K.L., and Keith, M.K., 2014, Geologic and physiographic controls on bed-material yield, transport, and channel morphology for alluvial and bedrock rivers, western Oregon: Geological Society of America Bulletin, v. 126, no. 3-4, p. 377-397. [Also available at https://doi.org/ 10.1130/B30831.1.]

Rouse, H.L., 1994, Measurement of bedload gravel transport-The calibration of a self-generated noise system: Earth Surface Processes and Landforms, v. 19, no. 9, p. 789-800. [Also available at https://doi.org/10.1002/ esp.3290190905.]

Southard, R.E., and Veilleux, A.G., 2014, Methods for estimating annual exceedance-probability discharges and largest recorded floods for unregulated streams in rural Missouri: U.S. Geological Survey Scientific Investigations Report 2014-5165, 39 p., accessed December 18, 2019, at https://doi.org/10.3133/sir20145165.

Teledyne Marine, 2019, Teledyne Marine WinRiver II software user's guide: Poway, Calif., Teledyne Marine, Inc., 4 p., accessed December 17, 2019, at http://www.teledynemarine.com/Documents/Brand\%20 Support/RD\%20INSTRUMENTS/Technical\%20Resources/ Manuals\%20and\%20Guides/Workhorse/WinRiver\%20 II\%20User\%20Guide_Sep19.pdf.

Teledyne RD Instruments, 2014, RiverPro ADCP-Intelligent river discharge measurement system: Poway, Calif., Teledyne RD Instruments, Inc., 2 p., accessed December 17, 2019, at http://www.teledynemarine.com/Lists/Downloads/ riverpro_datasheet_lr.pdf.

Thorne, P.D., 1985, The measurement of acoustic noise generated by moving artificial sediments: The Journal of the Acoustical Society of America, v. 78, no. 3, p. 1013-1023. [Also available at https://doi.org/10.1121/1.393018.]

Trimble Navigation Limited, 2009, User guide-Trimble R8 GNSS Receiver, Trimble R6/5800 GPS Receivers: Dayton, Ohio, Trimble Navigation Limited, 84 p., accessed December 17, 2019, at http://trl.trimble.com/docushare/ dsweb/Get/Document-666215/R8-R6-5800_v400A_ UserGuide.pdf.

Upper Colorado River Wild and Scenic Stakeholder Group, [SG], 2012, Upper Colorado River Wild and Scenic Stakeholder Group Management Plan: Upper Colorado River Wild and Scenic Stakeholder Group, 71 p., accessed December 9, 2019, at https://www.upcowildandscenic.com/ uploads/1/2/9/6/1296822/20120110_upper_co_river_ws_ mgmt_plan_alternative.pdf. 
Upper Colorado River Wild and Scenic Stakeholder Group, [SG], 2018, Request for proposals-Flushing flows 2018: Upper Colorado River Wild and Scenic Stakeholder Group, 7 p., accessed December 9, 2019, at https://www.upcowildandscenic.com/uploads/1/2/9/6/ 1296822/2018_08_27_flushing_flow_rfp.pdf.

U.S. Geological Survey [USGS], 2019a, USGS water data for the Nation: U.S. Geological Survey National Water Information System database, accessed December 19, 2019, at https://doi.org/10.5066/F7P55KJN.

U.S. Geological Survey, [USGS], 2019b, StreamStats: U.S. Geological Survey website, accessed December 9, 2019, at https://streamstats.usgs.gov/ss/.

U.S. Geological Survey [USGS], 2020, Peak Streamflow for Colorado-USGS 09058000 Colorado River near Kremmling, CO: U.S. Geological Survey National Water Information System database, accessed February 10, 2020, at https://doi.org/10.5066/F7P55KJN [Site information directly accessible at https://nwis.waterdata.usgs.gov/co/ nwis/peak/?site_no $=09058000 \&$ agency_cd $=$ USGS.]
Veilleux, A.G., Cohn, T.A., Flynn, K.M., Mason, R.R., Jr., and Hummel, P.R., 2014, Estimating magnitude and frequency of floods using the PeakFQ 7.0 program: U.S. Geological Survey Fact Sheet 2013-3108, 2 p., accessed December 18, 2019, at https://doi.org/10.3133/fs20133108.

Whitis, D., and Vinson, B., 2017, Guide to the upper Colorado River, Kremmling to Dotsero, Colorado: Buda, Tex., RiverMaps, LLC, 39 p.

Wilcock, P.R., Kondolf, G.M., Matthews, W.V.G., and Barta, A.F., 1996, Specification of sediment maintenance flows for a large gravel-bed river: Water Resources Research, v. 32, no. 9, p. 2911-2921, accessed December 18, 2019, at https://doi.org/10.1029/96WR01627.

Wolman, M.G., 1954, A method of sampling coarse river-bed material: Transactions-American Geophysical Union, v. 35, no. 6, p. 951-956. [Also available at https://doi.org/ 10.1029/TR035i006p00951.]
Director, USGS Colorado Water Science Center

Denver Federal Center

Box 25046, Mail Stop 415

Denver, CO 80225

(303) 236-6901

Or visit the Colorado Water Science Center website at

https://www.usgs.gov/centers/co-water 
